\title{
Recalibrating our tools? Analysing the congruence between instruments to measure the supply- and demand sides of populism
}

\author{
José Javier Olivas \\ Universidad Nacional de Educación a Distancia (UNED) \& London School of \\ Economics and Political Science (LSE) \\ J.J.Olivas-Osuna@,1se.ac.uk \\ José Rama \\ Universidad Autónoma de Madrid (UAM) \& King's College London (KCL) \\ jose.rama@uam.es
}

\begin{abstract}
This article examines the congruence between measurements of the demand and the supply-sides of populism. Theoretically voters exhibiting a higher degree of populist attitudes and beliefs are expected to be more prone to support parties classified as populist. However, this hypothesis has not been systematically tested in the literature. Our analysis based on the Comparative Studies of Electoral Systems (CSES Module 5) dataset, suggests that this expected congruence between 'populist' attitudes and likelihood of voting for 'populist parties' is only partial. We identify three main potential causes of such mismatch which should be taken into consideration when developing future tools to capture populism: (i) problems with the choice and design of attitudinal items; (ii) problems in the assessment of parties; (iii) instrument biases which make them more effective with some particular varieties of populism.
\end{abstract}

Keywords: populism, populist attitudes, political parties, voting, methodology 
Political scientists have traditionally developed different methodologies and typologies to classify political parties (Castles and Mair, 1984; Gunther and Diamond 2003; Coppedge, 1997; Mair and Mudde, 1998). However, categorizing parties is rarely a straightforward exercise and frequent disagreements emerge about the classification of specific political options. In this sense, the area of populism studies is no exception and often experts disagree on whether a party should be considered as populist or not. ${ }^{i}$ Arguably, the classificatory efforts driven by the needs of comparative empirical analyses on the electoral success and behaviour of populist parties, may have overshadowed the efforts to deconstruct and better understand the concept of populism itself (Olivas Osuna 2020). Although, there is a widespread scholarly agreement on some of the key attributes associated with the phenomenon of populism (Moffitt 2016: 26), this field has always displayed variety of conceptualisation and ontological approaches to populism (Berlin 1968; Weyland 2001; Mudde 2004; Laclau 2005a; Rovira Kaltwasser et al. 2017: 14; Ostiguy et al. 2021). Since the definitional debate is not completely settled it is not surprising that some parties are classified as 'populist' or 'non-populist' in different studies.

However, and irrespective of the chosen ontological approach to populism, a major question remains unresolved and understudied: To what extent voters who display populist attitudes are more prone to support populist parties? This theoretical question involves some methodological challenges that need to be addressed. Can we reliably classify parties and voters as populist or non-populist? Do we have appropriate instruments to measure populism?

The classification of political parties into the categories of 'populist' and 'nonpopulist' has been a central goal in the literature (Rooduijn et al 2020). Several strategies and measurements of populism have been developed based on the analysis of discourses and policy proposals (Rooduijn and Pauwels 2011; Bernhard and Kriesi 2019; Polk et al. 2017). This is also what Mudde (2007), following a microeconomics analogy, refers to as 'supply-side' of populism. Similarly, another strand in the literature has focused on designing items and scales to assess the 'demand-side' of populism, i.e. populist attitudes and beliefs manifested or felt among citizens or voters (Hawkins et al. 2012; Akkerman et al. 2014). Although some authors have measured the propensity of voters displaying populist attitudes to support populist parties (e.g. Akkerman et al 2017; Van Hauwaert and Van Kessel 2018: 72; Marcos-Marne 2020), there are very few studies trying to connect the supply- and demand-sides of populism. 
Theoretically the supply- and demand-side of populism should be connected. For instance, if we assume that left-wing voters are more prone to support political parties displaying a left-wing ideology and proposing left-leaning policies, it seems logical to expect voters with a populist understanding of political dynamics to have a tendency to endorse parties that uphold populist discourses and ideas. Likewise, it is reasonable to expect that the parties which are considered populist target individuals who share populist worldviews and attitudes, and tailor their messages accordingly. A populist voter should have a higher likelihood to embrace the populist discourses than another type of (pluralist) voter. Moreover, as self-identification of voters in the left-right continuum is sometimes used by political scientists to characterize the nature of the party they support, it could be expected that populist beliefs and attitudes of voters be somehow taken into consideration when classifying parties as populist or non-populists.

This paper explores to what extent there is congruence between supply- and demandside measurements of populism. In this regard, we test whether the probability of supporting a party classified as 'populist' is directly correlated with individuals who display high levels of 'populist attitudes' in seventeen countries - eleven European and 6 non-European ones). Drawing on the Comparative Studies of Electoral Systems (CSES) Module 5 (Hobolt et al.2016) dataset that measures three dimensions of populist attitudes -i.e. attitudes toward elites, toward majority rule and democracy, and toward outgroups - via survey analysis, and assess political parties degree of populism based on country expert assessments, we demonstrate that, while there is statistically significant congruence between these supply- and demand-side measures of populism in countries such as Austria, Germany, Norway and Italy, congruence is only partial in France and Lithuania - only some populist attitudes dimensions are correlated with "populist" vote - , and null in other countries, such as Brazil, Korea and Greece.

\section{Measuring populism}

Populism cannot be consistently identified with a specific socio-economic group, type of policies or political ideology (Müller 2016: 11-19). The large and increasing set of movements termed as populist, each of them with different characteristics (Mudde 2004: 548-551), has contributed to the problem of conceptual stretching. The phenomenon adopts different features in different contexts. To the extent that Rodrik (2018: 12) defines populism as 'a loose label that encompasses a diverse set of movements', Bell (1992: 3) 
claims that 'populism is optimism about people's ability to make decisions about their lives', and Ţăranu (2012: 131) argues that this term 'covers more political and social realities than one single term would normally concentrate from a semantic point of view'. In this context of conceptual indeterminacy, it is not surprising that many authors (e.g. Norris and Inglehart, 2019; Rodrik, 2018; Hopkin and Blyth, 2019) have undertaken ambitious empirical studies about the emergence and success of populist parties without putting excessive emphasis on engaging in the debates about the conceptualisation and assessment of populism. In the following two sub-sections we explore the instruments currently used to measure populist attitudes and the criteria followed to classify parties as 'populist' and 'non-populist'.

\section{Measuring voters' populist attitudes}

Despite the alleged conceptual indeterminacy and the differences in the interpretations of the genus of populism mentioned earlier, most attempts to measure the demand-side of populism adopt an ideational approach and consider it as a 'thin-centred' ideology that characterizes politics as a Manichean struggle between the will of the homogenous people and the corrupt elite (Mudde 2004: 543; Hawkins and Rovira Kaltwasser 2018: 3). Most of the proponents of this ideational approach, acknowledge that populism is a multidimensional phenomenon and that populist attitudes lie at the intersection of several of such dimensions (Castanho Silva et al. 2018).

One of the most influential, and widely used, instruments to measure populist attitudes is the scale designed by Akkerman, Mudde and Zaslove (2014), which is built upon the work of Hawkins et al. (2012) and captures with eight items, ${ }^{\text {ii }}$ three broad dimension of populism: (i) the notion of popular sovereignty, (ii) anti-elitism, and (iii) a Manichean worldview. This scale initially designed and tested empirically in the Netherlands has been later applied in different case studies, (Spruyt, Keppens and van Droogenbroeck 2016; Meléndez and Rovira Kaltwasser 2019; Zanotti and Rama 2020), and cross-country surveys (Van Hauwaert and Van Kessel 2018). Following this line of research, Castanho Silva et. al (2020) propose a scale which expands the number of items but keeps the focus on the same three core dimensions. More recently, Van Hauwaert et al. (2020) suggest a refinement of the scale of Akkerman et al. (2014) by identifying the 'best-three' performing items.

There are other relevant and slightly different approaches to the measurement of the demand-side of populism. For instance, Elchardus and Spruyt (2016) use a four-item scale 
that tries to capture different aspects of people centrism and anti-elitism, paying special attention to the sense of disconnect with experts and politicians. Oliver and Rahn (2016) propose a scale that focuses on anti-elitism, mistrust of experts and national affiliation. Schultz et al. (2018) use fifteen-item instrument to identify anti-elitism, popular sovereignty, and understanding of the people as being homogenous and virtuous. Finally, Hobolt et al. (2016) instrument to measure populism within the CSES Module 5. (further analysed in the following sections) focuses on attitudes toward political elites, out-groups, representative democracy and majority rule.

\section{Measuring populism in political parties}

Despite some divergences in terms of specific survey items, wording of questions, and dimensions included, overall, the abovementioned scales of populist attitudes follow largely similar methodological and conceptual approaches (Castanho Silva et al. 2020; Van Hauwaert et al., 2020). However, there seem to be more diversity in terms of methodologies, as well as specific attributes and dimensions taken into consideration, in the instruments used to assess the supply-side of populism. On the one hand, some authors base their measurements on the analysis of textual material. For instance, Hawkins (2009), in his analysis of speeches from Latin American political leaders, introduces the holistic grading technique, this requests coders familiarised with the definition of populism, to interpret whole texts, rather than words and sentences as in most content analysis research, and give a single mark in a three-point scale 0 ('non-populist or pluralist'), 1 ('mixed'), or 2 ('populist') (Hawkins 2009: 1050). Among several other empirical works, this approach has inspired the Global Populism Database which covers 215 leaders in 66 countries (Hawkins et al. 2019).

Bernhard and Kriesi (2019: 1196) measure the degree of populism by analysing press releases issued by political parties in parliamentary elections in eleven European countries. They also use a classical content analysis approach but analyse three ideational subdimensions: people centrism, anti-elitism and popular sovereignty. On the other hand, Pauwels (2011) adopts a computerised quantitative text analysis drawing on a dictionarybased approach. He analyses internally and externally oriented party literature by identifying words associated to populism - e.g. 'the people', 'elite', 'establishment' and 'corruption'-, and to other categories, such as conservative values, environmental issues, immigration, liberalism, progressive issues, nationalism, and law and order 
(Pauwels 2011: 104-105). Rooduijn and Pauwels (2011) launched a similar computerbased study on party manifestos in four countries.

Additionally, there are several projects that measure and classify parties based on expert surveys. For instance, drawing from the 2014 Chapel Hill Expert Survey, Polk et al. (2017) assess political parties' populism via the observed salience of antiestablishment and anti-elite rhetoric, as well as the emphasis displayed by parties on reducing political corruption. iii The PopuList project (Rooduijn et al. 2020) establishes peer reviewed unidimensional and dichotomous classification of populist, far right, far left and/or Eurosceptic parties in 30 countries. ${ }^{\text {iv }}$ Wiesehomeier (2018) uses two waves of expert surveys to measure the degree of populism in 165 political parties and 18 presidents in 18 Latin American countries. She focuses on two dimensions: peoplecentrism and anti-elite morality and adopts a 'bundle approach' combining different attributes in a single metric on a continuum between populist and pluralist poles of dimensions: people-centrism and moral anti-elitism. Meijers and Zaslove (2020a) elaborate on the multidimensionality of the populist construct in their ambitious Populism and Political Parties Expert Survey (POPPA) conducted in 28 European countries and covering 250 political parties. Their instrument includes 16 items and captures five dimensions: Manichean worldview, indivisible people, general will, people-centrism and anti-elitism (Meijers and Zaslove 2020a: 11).

Even larger in scope, Norris' (2020: 9) Global Party Survey, is presented as a departure from the ideational tradition and designed to estimate ideological values, issue positions and the degree of populist rhetoric, covering 1,052 parties in 163 countries. This expert survey asks respondents to place parties on a 11-point scale from 0 ('Strongly favors pluralist rhetoric') to 10 ('Strongly favors populist rhetoric'), ${ }^{\mathrm{v}}$ and adds other five alternative indicators aiming to capture two dimensions: 1) the only legitimate authority lies with 'the people', and 2) the critique to the corrupt, self-serving and out of touch 'establishment' (Norris 2020: 2-9). Similarly, the CSES Module 5 (2020) also offers an evaluation of political parties according to their degree of populism. Experts are given Albertazzi and McDonnell's (2008: 3) definition of populism and requested to assign score from 0 ('not at all populist') to 10 ('very populist').

In sum, there are several competing approaches to measure the degree of populism of political parties. Although, most of these instruments have been developed based on similar, often ideational, definitions of populism, they diverge in several aspects. Not all studies embrace degreeism or the multidimensionality of the concept. Moreover, while 
most demand-side studies use large-n surveys on citizen's views as source of data, those on political parties diverge in what is considered the specific object of analysis. Some of them circumscribe their assessments to party manifestos or political communications, while others are based upon wider assessments on parties' policies, strategies or rhetoric.

\section{Data and Methodology}

This paper develops an analysis of congruence of demand and supply-side measurements of populism to illustrate some challenges and limitations associated to the existing approaches to estimate levels of populism in citizens and political parties. We have selected CSES Module 5 'Democracy Divided? People, Politicians and the Politics of Populism' because it is currently the sole research project which offers publicly available data on both, the degree of populism of political parties and voters' attitudes. Additionally, it covers countries from several continents.

CSES Module 5 focuses on three core dimensions: '(i) attitudes towards political elites; (ii) attitudes towards representative democracy and majority rule; (iii) attitudes towards out-groups' (Hobolt et al., 2016: 5-10). ${ }^{\text {vi }}$ By following this conceptualisation, they argue that the core aspect of populism is the clear distinction and antagonism between the (good) people and the (corrupt) elite ( Mudde and Rovira Kaltwasser, 2014). The political elite is accused of not acknowledging, understanding or caring about the needs people have and, consequently, not being able to deliver the public goods and services people need. In the CSES dataset question items Q4b, Q4c and Q4d measure such different aspects of negative attitudes towards the elite (Table 1). ${ }^{\text {vii }}$ 
Table 1. Eight items to measure populist attitudes, CSES Module $5^{\text {a }}$

\begin{tabular}{|c|c|c|c|}
\hline Items & Original & Wording of the question & Populist dimension \\
\hline Pop $1^{b}$ & $\mathrm{Q} 4 \mathrm{a}$ & $\begin{array}{l}\text { What people call compromise in } \\
\text { politics is really just selling out } \\
\text { one's principles. }\end{array}$ & $\begin{array}{l}\text { Democracy: Challenges to } \\
\text { representative democracy }\end{array}$ \\
\hline Pop2 & $\mathrm{Q} 4 \mathrm{~b}$ & $\begin{array}{l}\text { Most politicians do not care about } \\
\text { the people. }\end{array}$ & $\begin{array}{l}\text { Elite: Attitudes toward political } \\
\text { elites }\end{array}$ \\
\hline Pop3 & Q4c & Most politicians are trustworthy & $\begin{array}{l}\text { Elite: Attitudes toward political } \\
\text { elites }\end{array}$ \\
\hline Pop4 & Q4d & $\begin{array}{l}\text { Politicians are the main problem in } \\
\text { COUNTRY }\end{array}$ & $\begin{array}{l}\text { Elite: Attitudes toward political } \\
\text { elites }\end{array}$ \\
\hline Pop5 & Q4e & $\begin{array}{l}\text { Having a strong leader in } \\
\text { government is good for } \\
\text { COUNTRY even if the leader } \\
\text { bends the rules to get things done. }\end{array}$ & $\begin{array}{l}\text { Democracy: Challenges to } \\
\text { representative democracy }\end{array}$ \\
\hline Pop6 & Q4f & $\begin{array}{l}\text { The people, and not politicians, } \\
\text { should make our most important } \\
\text { policy decisions. }\end{array}$ & $\begin{array}{l}\text { Democracy: Challenges to } \\
\text { representative democracy }\end{array}$ \\
\hline Pop7 & Q5a & $\begin{array}{l}\text { It is better for society if minorities } \\
\text { maintain their distinct customs and } \\
\text { traditions. }\end{array}$ & $\begin{array}{l}\text { Out-groups: Attitudes toward } \\
\text { out groups }\end{array}$ \\
\hline Pop8 & Q6a & $\begin{array}{l}\text { How important do you think the } \\
\text { following is for being truly } \\
\text { [NATIONALITY]. very important, } \\
\text { fairly important, not very } \\
\text { important, or not important at all? } \\
\text { a. To have been born in } \\
\text { [COUNTRY] }\end{array}$ & $\begin{array}{l}\text { Out-groups: Attitudes toward } \\
\text { out groups }\end{array}$ \\
\hline
\end{tabular}

Notes a Trying to be parsimonious, we just select 8 indicators for populism: 3 items to measure anti-elite; 3 items to measure democracy and 2 items to measure attitudes towards out groups. We have not included Q7, Q5b-d and Q6b-d. Additional robustness checks confirm that the findings keep in the same direction

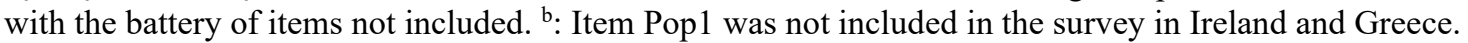

Source: Own elaboration based on CSES Module 5 (2020)

The perceived 'institutional crisis of representation' resulting from the wrongdoings and incompetence of the elite (Rooduijn et al.2014) is the second populist dimension captured in the CSES study. Comparative and longitudinal data show that, the higher the support for populist parties, the lower the levels of liberal democracy (Rama and Casal Bértoa 2020). Populists usually propose to overcome this problem of representation either by empowering a strong charismatic leader who would embody and voice the will of the people (Müller 2016: 32-38), or by involving more directly 'the people' in direct decision making (Mohrenberg et al. 2019). Compromise also clashes with the antagonistic and Manichean view of politics dynamics and as such is perceived as a sort of betrayal to the interest of the people. These ideas on the populist conception of democracy are captured by items Q4a, Q4e and Q4f in the CSES dataset (Table 1). 
Finally, the CSES Module 5 offers additional survey items related to attitudes toward out-groups. In-group homogeneity and exclusion are also key elements of populists' interpretation of society (Jagers and Walgrave 2007: 323) The underserving and corrupt minorities - e.g. 'the elite', 'the colonisers', 'the immigrants' - , do not really belong to the demos or the 'heartland'(Taggart, 2000), the 'true people' must fight to 'have their country back' (Panizza 2017: 409-411). Items Q5a and Q6a in the CSES dataset reflect these ideas (Table 1). ${ }^{\text {viii }}$ Regarding the assessment of the supply-side of populism, CSES Module 5's country experts are presented with a definition and asked to assess on a 11point scale the degree of populism of each political part. ${ }^{\text {ix }}$ This assessment was made by a variable number of country experts, who may or not be specialist on the area of populism, ranging from 1 (Australia, Hungary and Italy country reports) to 43 experts (Greece report) (Table 2). The documentation provided $^{x}$ does not seem to indicate consistency checks across cases. There is at least one country, Chile, containing some apparent mistakes and two countries, Taiwan and Turkey, on which no score on populism was provided by the country experts. ${ }^{x i}$ Given some of the abovementioned limitations, we include Meijers and Zaslove's POPPA (2020b) measurement as a robustness check in the analysis of congruence between the CSES classification of political parties and the CSES data on populist attitudes. Table 2 shows the parties that were considered populist, i.e. those that received a score of more than 5 on the 11 scale in the CSES and POPPA datasets. ${ }^{\text {xii }}$ 
Table 2. List of parties classified as populist (score $>5$ ) ${ }^{\text {a }}$

\begin{tabular}{|c|c|c|}
\hline $\begin{array}{l}\text { Country (election } \\
\text { year) }\end{array}$ & Populist parties CSES (2020) & $\begin{array}{l}\text { Populist parties Meijers \& } \\
\text { Zaslove's POPPA }(2020 \mathrm{~b})^{\mathrm{b}}\end{array}$ \\
\hline Australia (2019) & $\begin{array}{l}\text { One Nation (7) } \\
\text { United Australia ( } 8 \text { ) } \\
\text { (based on the assessment of } 1 \text { country expert) }\end{array}$ & \\
\hline Austria (2017) & $\begin{array}{l}\text { Austrian People's Party [ÖVP] (6) } \\
\text { Freedom party of Austria [FPÖ] (9) } \\
\text { Liste Peter Pilz (6) } \\
\text { (based on } 11 \text { country experts) }\end{array}$ & $\begin{array}{l}\text { Freedom party of Austria } \\
\text { [FPÖ] }(8.89)\end{array}$ \\
\hline Brazil (2018) & $\begin{array}{l}\text { AVANTE - 'Go forward' (6) } \\
\text { DC - Christian Democracy (6) } \\
\text { DEM - Democrats (6) } \\
\text { MDB - Brazilian Democratic Movement (7) } \\
\text { PATRI/Patriota- Patriot (7) } \\
\text { PCdoB - Communist Party of Brazil (8) } \\
\text { PDT - Democratic Labour Party (8) } \\
\text { PODE/Podemos - 'We can' (7) } \\
\text { PP - Progressive Party (6) } \\
\text { PPS - Popular Socialist Party (6) } \\
\text { PR - Republican Party } \\
\text { PRB - Brazilian Republican Party (7) } \\
\text { PROS - Republican Party of Social Order (6) } \\
\text { PRP - Progressive Republican Party (7) } \\
\text { PSC - Christian Social Party } \\
\text { PSD - Social Democratic Party (6) } \\
\text { PSL - Liberal Social Party (10) } \\
\text { PT - Workers' Party (10) } \\
\text { PTB - Brazilian Labour Party (8) } \\
\text { SD - Solidarity (7) } \\
\text { (based on } 3 \text { country experts) }\end{array}$ & \\
\hline France (2017) & $\begin{array}{l}\text { La République en Marche (6) } \\
\text { France Insoumise ( } 8) \\
\text { Front National [FN] (10) } \\
\text { (based on } 3 \text { country experts) }\end{array}$ & $\begin{array}{l}\text { Front National [FN] (9.07) } \\
\text { France Insoumise (8.44) } \\
\text { France Arise (DLF) (7.42) } \\
\text { New Anticapitalistic Party } \\
{[\text { NPA] (7.75) }} \\
\text { Parti Communist (8.71) }\end{array}$ \\
\hline Germany (2017) & $\begin{array}{l}\text { Alternative for Germany [AfD] (7) } \\
\text { (based on } 3 \text { country experts) }\end{array}$ & $\begin{array}{l}\text { Alternative for Germany [AfD] } \\
(9.44)\end{array}$ \\
\hline Greece (2015) & $\begin{array}{l}\text { Synaspismos tis Rizospatikis Aristeras } \\
\text { [SYRIZA] (8) } \\
\text { Laikos Syndesmos - Chrisi Avgi (Golden } \\
\text { Dawn) [LS- XA] (8) } \\
\text { Kommounistiko Komma Ellados [KKE] (8) } \\
\text { Anexartitoi Ellines [ANEL] (7) } \\
\text { Enosi Kentroon [EK] (6) } \\
\text { (based on } 43 \text { country experts) }\end{array}$ & $\begin{array}{l}\text { Synaspismos tis Rizospatikis } \\
\text { Aristeras [SYRIZA] (7.63) } \\
\text { Laikos Syndesmos - Chrisi } \\
\text { Avgi (Golden Dawn) [LS-XA] } \\
(9.12) \\
\text { Kommounistiko Komma } \\
\text { Ellados [KKE] (7.51) } \\
\text { Anexartitoi Ellines [ANEL] } \\
(8.46) \\
\text { Enosi Kentroon [EK] (6.3) } \\
\text { Popular Unity [LAE] (8.9) }\end{array}$ \\
\hline $\begin{array}{l}\text { Hong } \\
(2016)\end{array}$ & $\begin{array}{l}\text { Democratic Alliance for Betterment and } \\
\text { Progress of Hong Kong ( } 6) \\
\text { Hong Kong Federation of Trade Unions ( } 8) \\
\text { Youngspiration (8) } \\
\text { (based on } 2 \text { country experts) }\end{array}$ & \\
\hline
\end{tabular}




\begin{tabular}{|c|c|c|}
\hline Hungary (2018) & $\begin{array}{l}\text { FIDESZ - Hungarian Civic Alliance (9) } \\
\text { Christian Democratic People's Party [KDNP] } \\
\text { (9) } \\
\text { Hungarian Socialist Party [MSZP] (6) } \\
\text { Movement for a Better Hungary [JOBBIK] (7) } \\
\text { (based on } 1 \text { country expert) }\end{array}$ & $\begin{array}{l}\text { FIDESZ - Hungarian Civic } \\
\text { Alliance (9.01) } \\
\text { Movement for a Better } \\
\text { Hungary [JOBBIK] (7.3) }\end{array}$ \\
\hline Iceland (2017) & $\begin{array}{l}\text { Centre Party (6) } \\
\text { People's Party }(6) \\
\text { (based on } 3 \text { country experts) }\end{array}$ & \\
\hline Ireland (2017) & $\begin{array}{l}\text { Sinn Féin [SF] (6) } \\
\text { United Left Alliance ( } 7 \text { ) } \\
\text { (based on } 2 \text { country experts) }\end{array}$ & Sinn Féin [SF] (6.23) \\
\hline Italy (2018) & $\begin{array}{l}\text { Movimento } 5 \text { Stelle / } 5 \text { Star Movement [M5S] } \\
\text { (10) } \\
\text { Lega / League (9) } \\
\text { Fratelli d'Italia / Brothers of Italy [FdI] (7) } \\
\text { (based on } 1 \text { country expert) }\end{array}$ & $\begin{array}{l}\text { Movimento } 5 \text { Stelle / } 5 \text { Star } \\
\text { Movement [M5S] }(9.45) \\
\text { Lega / League (8.60) } \\
\text { Forza Italia [FI] (5.56) } \\
\text { Fratelli d'Italia / Brothers of } \\
\text { Italy [FdI] (7.44) }\end{array}$ \\
\hline Lithuania (2016) & $\begin{array}{l}\text { Anti-corruption Coalition of N. Puteikis and K. } \\
\text { Krivickas (9) } \\
\text { Lithuanian Polish Electoral Action - League of } \\
\text { Christian Families (6) } \\
\text { Order and Justice Party [TT] (8) } \\
\text { (based on } 3 \text { country experts) }\end{array}$ & $\begin{array}{l}\text { Order and Justice Party [TT] } \\
(7.07)\end{array}$ \\
\hline $\begin{array}{l}\text { Montenegro } \\
(2016)\end{array}$ & $\begin{array}{l}\text { Democratic front (8) } \\
\text { DEMOS (6) } \\
\text { Socialist People Party (6) } \\
\text { Democrats (6) } \\
\text { (based on } 6 \text { country experts) }\end{array}$ & \\
\hline Norway (2017) & $\begin{array}{l}\text { The Progress Party ( } 7 \text { ) } \\
\text { (based on } 5 \text { country experts) }\end{array}$ & \\
\hline $\begin{array}{ll}\text { New } & \text { Zeeland } \\
(2017) & \end{array}$ & $\begin{array}{l}\text { Labour (6) } \\
\text { National (7) } \\
\text { New Zealand First (9) } \\
\text { ACT (7) } \\
\text { Mana (6) } \\
\text { (based on } 1 \text { country expert) }\end{array}$ & \\
\hline $\begin{array}{l}\text { South Korea } \\
(2016)\end{array}$ & $\begin{array}{l}\text { People's Party (7) } \\
\text { (based on } 5 \text { country experts) }\end{array}$ & \\
\hline $\begin{array}{ll}\text { United } & \text { States } \\
(2016) & \end{array}$ & $\begin{array}{l}\text { Republican Party ( } 8 \text { ) } \\
\text { Libertarian Party (9) } \\
\text { (based on } 2 \text { country experts) }\end{array}$ & \\
\hline
\end{tabular}

Source: own elaboration base on CSES Module 5, 14 May 2020 update and Meijers \& Zaslove (2020b).

As previously mentioned, we want to assess the extent to which populist attitudes indicators (Table 1) correlate with the higher tendency of voters to support populist forces. It is expected that if these items correctly measure populist attitudes, voters displaying a higher degree of populist attitudes should be more likely to cast a vote for populist parties. The countries selected to examine the relationship between the demand 
and the supply side of populism are Australia, Austria, Brazil, France, Germany, Greece, Hong Kong, Hungary, Iceland, Italy, Ireland, South Korea, Lithuania, Montenegro, New Zeeland, South Korea, and the United States of America, xiii i.e. eleven European countries and six non-European ones.

We run specific logistic regressions in each country in order to measure the relationship between each one of the eight items capturing populist attitudes in the CSES survey (Table 1) and the likelihood to vote for a populist party (additional models were used as robustness checks) ${ }^{\text {xiv }}$ In this sense, we make the original continuous classification dichotomous, considering as non-populist those parties with a score of 5 or less and populist those with scores from 6 to $10 .^{\mathrm{xv}}$ Table 3 displays the expected effect of each item on dependent variable - i.e. support for populist parties - , positive if the wording of the question is theoretically linked to populist attitudes or negative, when the relationship is expected to be in the opposite sense..$^{\mathrm{xi}}$ 
Table 3. Expected effect of populist dimensions upon the vote for populist parties.

\begin{tabular}{|c|c|c|c|c|}
\hline Items & $\begin{array}{l}\text { Populist } \\
\text { dimension }\end{array}$ & Wording of the question & Possible values & $\begin{array}{l}\text { Expected } \\
\text { effect }\end{array}$ \\
\hline Pop1 & Democracy & $\begin{array}{l}\text { What people call compromise in } \\
\text { politics is really just selling out one's } \\
\text { principles. }\end{array}$ & $\begin{array}{l}(1=\text { strongly agree } \\
-5=\text { strongly } \\
\text { disagree })\end{array}$ & Negative \\
\hline Pop2 & Elite & $\begin{array}{l}\text { Most politicians do not care about the } \\
\text { people. }\end{array}$ & $\begin{array}{l}(1=\text { strongly agree } \\
-5=\text { strongly } \\
\text { disagree })\end{array}$ & Negative \\
\hline Pop3 & Elite & Most politicians are trustworthy & $\begin{array}{l}(1=\text { strongly agree } \\
-5=\text { strongly } \\
\text { disagree })\end{array}$ & Positive \\
\hline Pop4 & Elite & $\begin{array}{l}\text { Politicians are the main problem in } \\
\text { COUNTRY }\end{array}$ & $\begin{array}{l}\text { (1=strongly agree } \\
-5=\text { strongly } \\
\text { disagree })\end{array}$ & Negative \\
\hline Pop5 & Democracy & $\begin{array}{l}\text { Having a strong leader in } \\
\text { government is good for COUNTRY } \\
\text { even if the leader bends the rules to } \\
\text { get things done. }\end{array}$ & $\begin{array}{l}(1=\text { strongly agree } \\
-5=\text { strongly } \\
\text { disagree })\end{array}$ & Negative \\
\hline Pop6 & Democracy & $\begin{array}{l}\text { The people, and not politicians, } \\
\text { should make our most important } \\
\text { policy decisions. }\end{array}$ & $\begin{array}{l}(1=\text { strongly agree } \\
-5=\text { strongly } \\
\text { disagree })\end{array}$ & Negative \\
\hline Pop7 & Out-groups & $\begin{array}{l}\text { It is better for society if minorities } \\
\text { maintain their distinct customs and } \\
\text { traditions. }\end{array}$ & $\begin{array}{l}(1=\text { strongly agree } \\
-5=\text { strongly } \\
\text { disagree })\end{array}$ & Negative \\
\hline Pop8 & Out-groups & $\begin{array}{l}\text { How important do you think the } \\
\text { following is for being truly } \\
\text { [NATIONALITY]... very important, } \\
\text { fairly important, not very important, } \\
\text { or not important at all? } \\
\text { a. To have been born in } \\
\text { [COUNTRY] }\end{array}$ & $\begin{array}{l}(1=\text { very important } \\
-4=\text { not important } \\
\text { at all })\end{array}$ & Negative \\
\hline
\end{tabular}

Source: Own elaboration based on CSES Module 5

Table 4 displays the number of observations, mean, standard deviation, minimum and maximum values of the variables considered in the logistic models. We include three controls (sociodemographic variables) in the models: Gender $(1=$ male); Year of birth (continuous variable) and Education level (1= University degree). The last column shows the variance inflation factors (VIFs) of all variables. All VIFs are well below the levels that would rise concerns of collinearity (James et al. 2017: 59-120); the mean VIF is 1.24 and the maximum one 1.71 (Pop1). 
Table 4. Description of variables

\begin{tabular}{lcccccc}
\hline Variable & Observations & Mean & Standard deviation & Min. & Max. & VIF \\
\hline Gender & 29.044 & 0.51 & 0.50 & 0 & 1 & 1.01 \\
Year of birth & 28.901 & 1968 & 17.41 & 1916 & 2002 & 1.08 \\
Education & 26.618 & 1.14 & 0.68 & 0 & 2 & 1.15 \\
Pop1 & 23.397 & 2.93 & 1.24 & 1 & 5 & 1.23 \\
Pop2 & 28.630 & 2.64 & 1.30 & 1 & 5 & 1.71 \\
Pop3 & 28.549 & 3.43 & 1.21 & 1 & 5 & 1.35 \\
Pop4 & 28.299 & 2.90 & 1.31 & 1 & 5 & 1.67 \\
Pop5 & 28.151 & 3.19 & 1.38 & 1 & 5 & 1.14 \\
Pop6 & 28.429 & 2.60 & 1.28 & 1 & 5 & 1.28 \\
Pop7 & 28.472 & 2.26 & 1.20 & 1 & 5 & 1.14 \\
Pop8 & 28.099 & 2.39 & 1.07 & 1 & 4 & 1.19 \\
\hline
\end{tabular}

Source: Own elaboration based on CSES Module 5

\section{Results}

Our analysis indicates that, although there is a significant statistical correlation between populist attitudes and support for parties classified as populist in the USA, Australia and most European countries, there are still many other countries (including, Brazil, New Zealand, South Korea, Hong Kong, Hungary, France, and Greece) where we fail to observe congruence between CSES Module 5 supply and demand measurements of populism. Figure 1 and 2 show the impact of the abovementioned eight attitudinal items, controlling by the sociodemographic factors (not shown), upon the probability to cast a vote for a populist party in six non-European (Figure 1) and eleven European countries (Figure 2).

One limitation of the logistic regression coefficients is that they do not provide information regarding the comparative magnitude of each covariate's effect. Therefore, after running the logistic regression we calculated their average marginal effects (AMEs) that capture the average changes in the probability of vote from a populist party instead of a non-populist party. ${ }^{x v i i}$ The AMEs are calculated as follows: for each observation of the dataset, the marginal effect of a given variable (holding all other independent variables constant) on our dependent variable is estimated, and then these estimations are averaged for all the observations (Williams 2012). Each horizontal line in Figure 1 represents an independent variable of the model, the point standing for the best estimation of its effect upon the dependent variable, and the horizontal line covering the $95 \%$ confidence interval. If a confidence interval crosses the vertical line drawn at the zero value of the horizontal axis (representing the absence of effects), the effect of the variable is not statistically significant. If it does not and is located to its right, the effect is positive and 
statistically significant; whereas if it is located to its left, the effect is negative and statistically significant.

Figure 1. Average marginal effects on the probability to cast a vote for a populist party, non-European countries
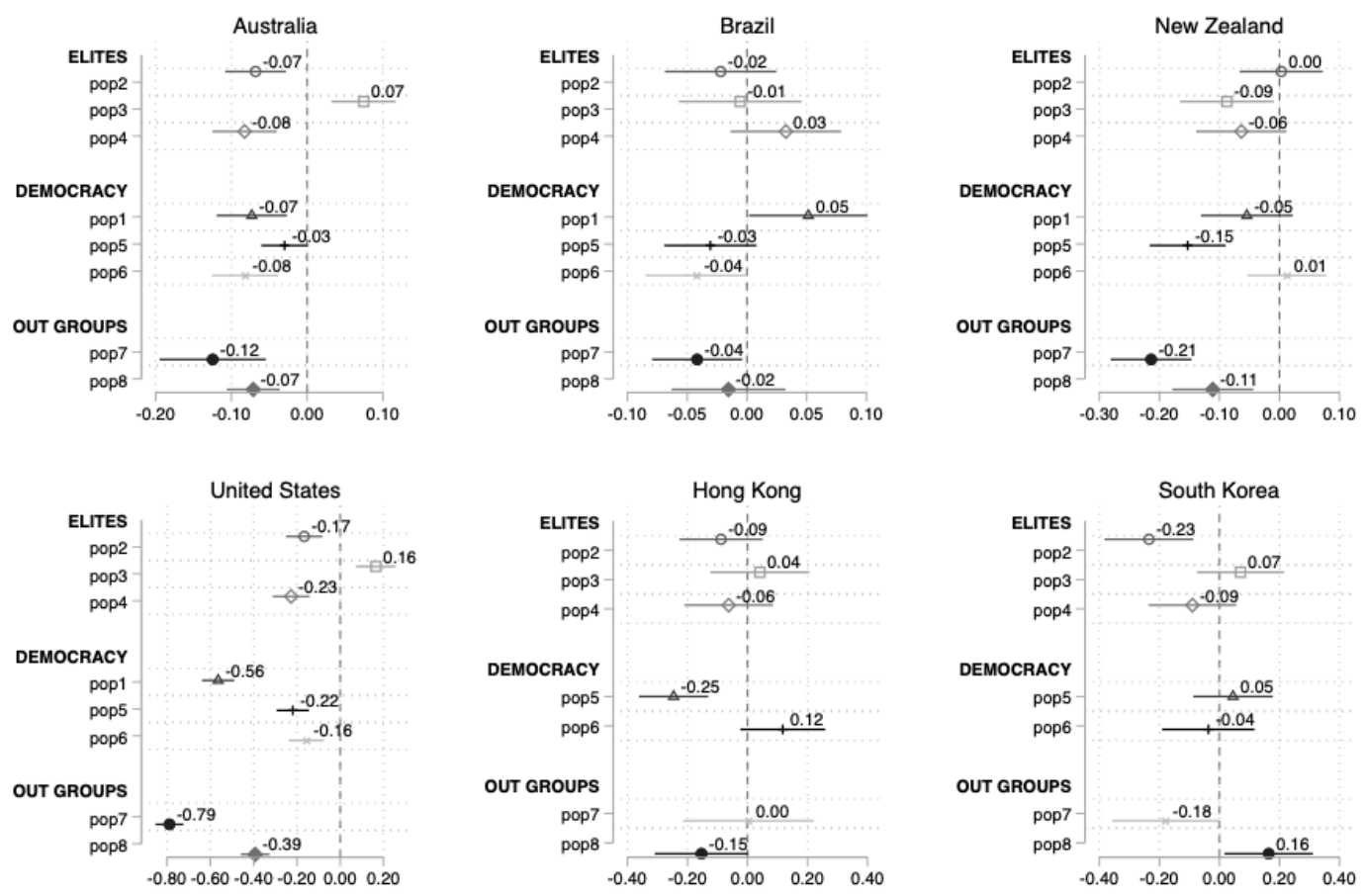

Source: Own elaboration based on CSES Module 5

Figure 1 clusters the eight items into three big blocks: negative attitudes towards elites (elite); democratic values (democracy) and out groups considerations (out-groups), following the three dimensions specified by Hobolt et al. (2016). In the case of Australia, with the exception of Pop5 (strong leader), items help to understand populist parties support, being Pop7 (minority rights) the one with the higher coefficient (-0.12). Brazil clearly means a case where the populist attitudes items do not seem correlated with support for this set of surmised populist political forces. Most of the items are non statistically significant (they touch the vertical line). Regarding New Zeeland, it is surprising that, while both of the items that measure the out-groups dimension are statistically significant and display high effects, the cluster of democracy and elite do not have any effect upon the likelihood to vote for a populist force. The cases of Hong Kong and South Korea goes in the same line than the Brazilian one, i.e. the populist attitudes items do not seem correlated with a higher probability to vote for parties presumed populist. USA is the non-European country with the best fit between CSES measurements of supply and demand-sides of populism, as all items help to understand the vote for 
populist leaders (the Republican Party and the Libertarian Party). Items Pop7 and Pop8 (both belonged to the out groups dimension), with -0.79 and -0.39 coefficients respectively, and Pop1 (democracy) (-0.56) are particularly helpful in explaining support for populist parties.

Figure 2. Average marginal effects on the probability to cast a vote for a populist party, European countries
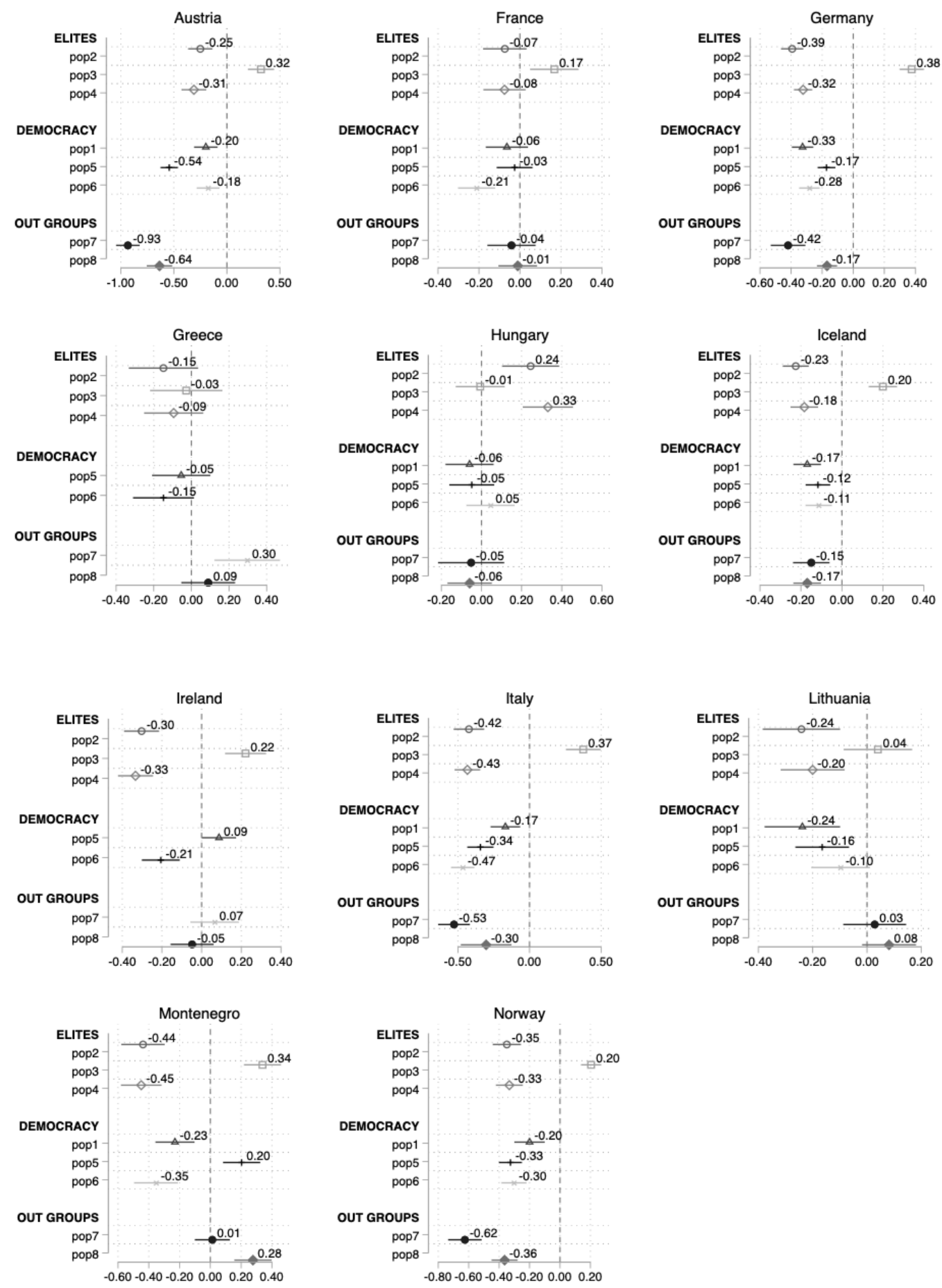

Source: Own elaboration based on CSES Module 5 
Figure 2 shows a greater explanatory capacity of the eight attitudinal items in the case of most of the European countries analysed, even controlling for sociodemographic variables. However, we still observe that in some countries -i.e. France, Hungary, Lithuania, Montenegro, Ireland and Greece - there is not significant correlation between some of the populism items and preference for populist parties. In Austria, Germany, Iceland, Italy and Norway the battery of items employed to measure populist attitudes works well as predictors. Items such as Pop5 (strong leader) and Pop7 (minority rights) exhibit high coefficients (-0.54 and, -0.93 , respectively). Similarly, in Germany -elite items Pop2 and Pop3 and out-groups item Pop7 display the strongest effect. Despite the wide ideological variety displayed by the Italian parties ranked as populist at the CSES Module 5 (M5S, Lega and Brothers of Italy), all the attitudinal items are statistically significant, follow the expected direction and exhibit high coefficients (specially Pop7, Pop6, Pop4 and Pop2). Norway and Iceland display a good congruence as well between the demand- and the supply-side. It is worth noting that in Norway, Pop7 (minority rights) obtains a relatively very high coefficient (-0.62), only lower than the one in Austria ($0.93)$ and the USA (-0.79). This is probably logical given that the only party considered populist in that country is the Progress Party, a populist radical right force with a notorious anti-immigration agenda. Pop7 is precisely the only item that is not significantly correlated with support to populist parties in Montenegro, although in this country Pop5 displays an effect opposite to the one we could theoretically expect.

Conversely, the capacity of these items to predict support for parties classified as populist is more limited or inexistent in other European cases. Only four items are statistically significant in the cases of Ireland (Pop2, Pop3, Pop4 and Pop6) and Lithuania (Pop1, Pop2, Pop4 and Pop5), none of which belong to the out-groups dimension. Only 2 items have a significant correlation in the cases of France (Pop3 and Pop6) and Hungary (Pop2 and Pop4) but in the latter items have an effect opposite the one expected. Finally, in Greece, the single item with statistically significant impact (Pop7) also goes in the opposite sense to the intention of the designers of the instrument. 
Figure 3. Average marginal effects on the probability to cast a vote for a populist party instead of non-populist parties (all countries in populist index)

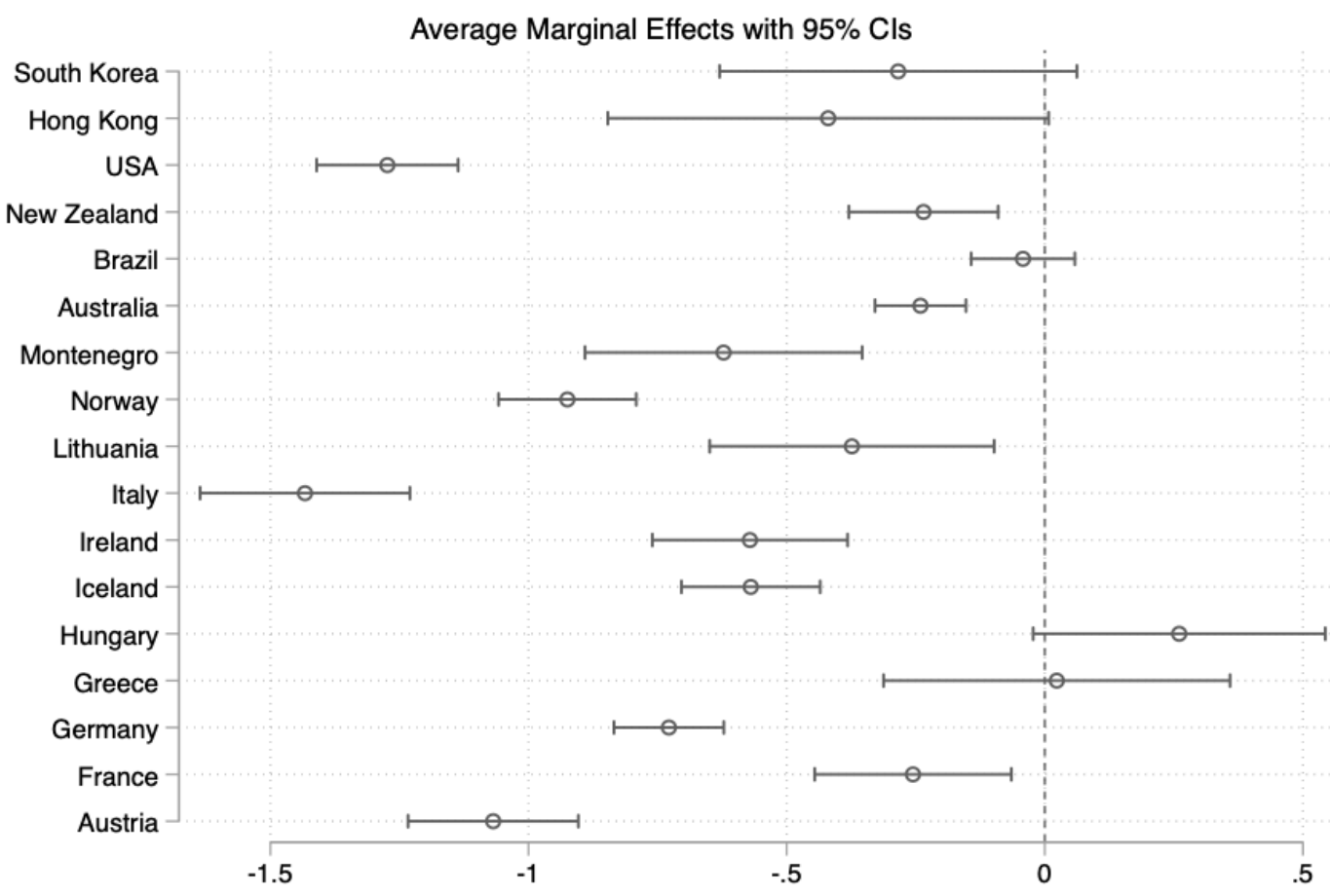

Source: Own elaboration based on CSES Module 5

Given the apparent limited ability of the CSES items to capture voters prone to support populist parties when considered individually, and inspired by Akkerman et al. (2014), we construct an additive index including the eight items of populism to check whether at least the combined presence of these populist beliefs serves as a predictor of support for populist parties ${ }^{\mathrm{xviii}}$. Figure 3 lays out the relationship between the unidimensional populist index and the probability to vote for a populist party country by country. There is no very significant improvement with respect to the previous itemized models. There are still 5 countries out of 17 with no statistically significant relation between populist attitudes and support for populist parties, two of which (Hungary and Greece) exhibit a negative coefficient.

Further research is required to discern whether the problem is associated to an unclear wording, contextual peculiarities or deeper theoretical considerations. Anyhow, the inability of the items in a populist attitudes scale to discriminate 'populist' from 'non populist citizens' can be one of the sources of the mismatch between supply- and demandside measurements. Next section explores three potential causes of the mismatch observed between CSES Module 5 measurements of supply and demand-side of populism, that could also affect other scales and classifications of populism: (i) problems 
with the design of items in attitudes surveys; (ii) problems with the experts' scores and classification of parties; (iii) some dimensions or attributes considered in supply and demand-side measurements may be specific to a type populism but not to all them.

\section{Discussion: How to understand the incongruence between the supply and the demand side measurement instruments?}

\section{Choice and design of attitudinal Items}

What if the incongruence is caused by the choice or design of attitudinal items? Although most scales rely on an ideational approach, there is not a widespread agreement on which are 'the best' items and in fact we observe little overlap across scales (Castanho Silva et al. 2020). There is always a risk that items do not properly capture the populist dimensions/attributes intended. Additionally, even if they prove effective in some case studies, certain wordings of items/questions do not travel well and elicit different interpretations in other country contexts. This may be the reason why some scales may yield some surprisingly different results in different countries. ${ }^{x i x}$

To prevent these problems, some scales are refined during their development by applying confirmatory factor analysis (CFA) (Akkerman et al. 2014; Schultz et al. 2018; Castanho Silva et al.2018) or item response theory (IRT) (Van Hauwaert and Van Kessel 2018; Van Hauwaert et al. 2020) as means to eliminate items that do not load sufficiently on the desired latent dimension. ${ }^{\mathrm{xx}}$ In order to assess the impact of each CSES Module 5 item upon the probability to support a populist party, and given their continuous nature, we use a graded response model (GRM) - that is an IRT model typically used in health and psychology related surveys (Depaoli et al.2018) - to analyse the relative fitness of each of the items in the CSES Module 5 instrument (see Figure 4). ${ }^{\mathrm{xx}}$

Our preliminary analysis of the 8 items mentioned above suggests that the CSES Module 5 attitudes scale items could benefit from further development or refinement. Out of the three dimensions that were meant to be captured (Hobolt et al. 2016: 5) only the items ascribed to the elite dimension (Pop2 and Pop4) display significant discriminatory power. The rest of the items - related to Democracy and Out-groups dimensionsdisplay somewhat flat information slopes and, therefore, could probably be either excluded as redundant, rephrased or replaced. ${ }^{x x i i}$ This seems to suggest that this instrument would benefit from further work of redesign, test, and validation of items. 
Further research is required to discern whether the problems encountered in some of the items, are associated to an unclear wording, contextual peculiarities or deepest theoretical considerations. In any case, this illustrates that the inability of some attitudinal items to discriminate 'populist' from 'non populist citizens' can be one of the sources of mismatch between supply and demand-side measurements.

Figure 4. Individual item characteristic curves

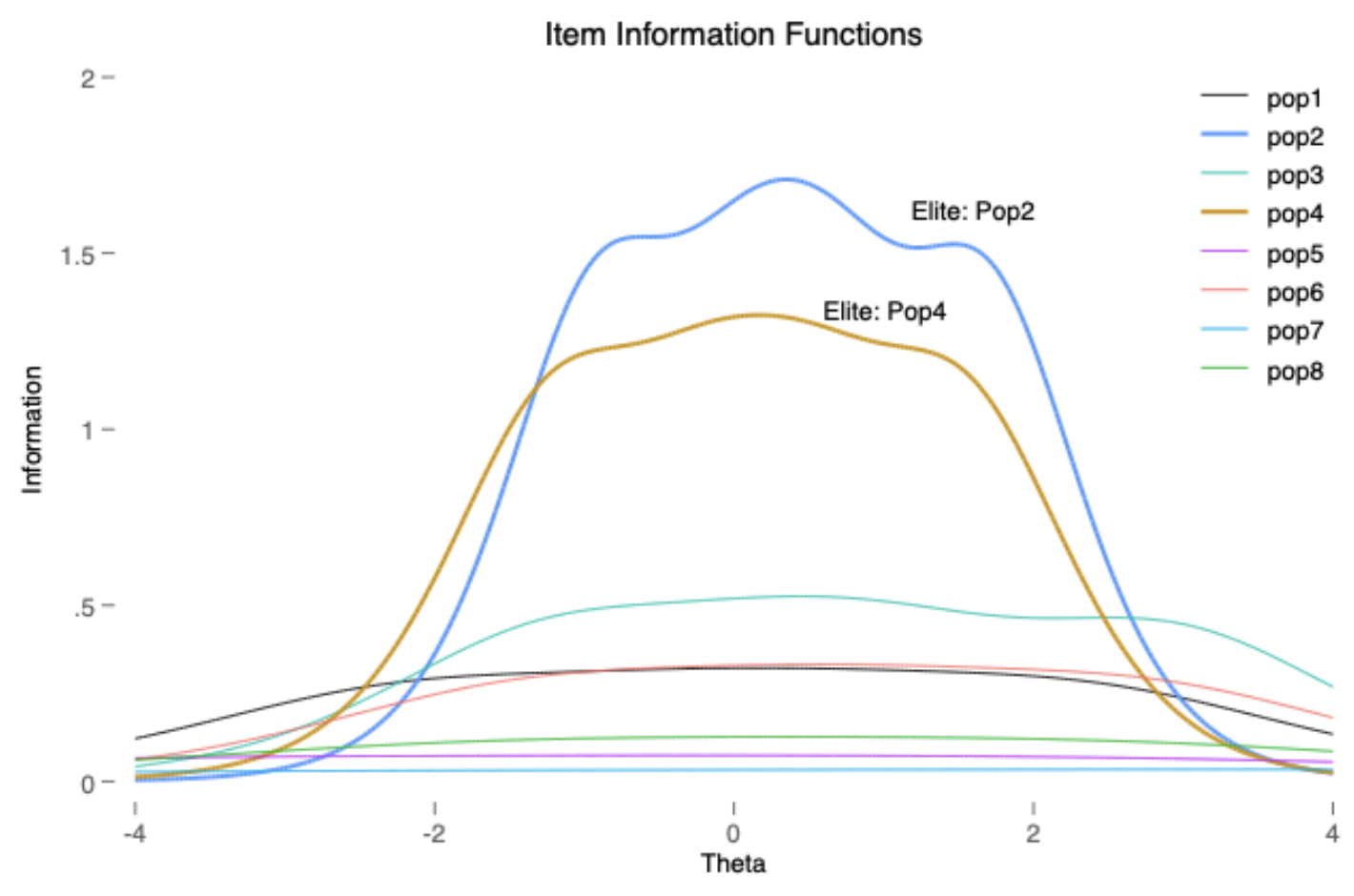

Source: Own elaboration based on CSES Module 5

\section{Problematic assessment of parties}

Lack of congruence could also be explained by problems in the methods used to assess the degree of populism and classify parties as populists or non-populists. The use of different criteria and definitions certainly has an impact on the score received by each party. Table 2 in the Data and Methods section shows the discrepancies between the CSES Module 5 and Meijer and Zaslove's POPPA (2020) classifications. Meijer and Zaslove's (2020) assessment is based on 294 responses from country-experts, selected on the basis of publications records, in 28 European countries. Unlike in the case of CSES, POPPA experts were not explicitly asked to assess populism, but a set of dimensions 
associated to this phenomenon in line with the ideational approach (Meijer and Zaslove 2020: 11).

Although some parties receive similar scores in both scales, we find significant differences in others. Some of them score much lower in the POPPA populism measurement, such as the Hungarian Socialist Party MSZP (-3.55 points difference), Austrian Liste Peter Pilz (-3.03 points difference), ÖVP (-2.2 points difference), and French La République en Marche (-1.57 points difference). On the other hand, some parties obtain a significantly higher score in the POPPA classification -i.e. the German AfD (2.44 points difference), Italian Forza Italia (1.56 difference) and the Greek ANEL (1.43 points difference). The French Communist Party, which according to Meijer and Zaslove's (2020) classification scores very high, was not assessed in the CSES expert survey.

Figure 5 and 6, replicate the analysis for France and Hungary - both displaying particularly poor congruence - but using Meijers and Zaslove's (2020b) POPPA scores (right panels) to estimate the dependent variable (Table 2). The result for the case of France shows a clear improvement in the level of congruence. With just the exception of Pop5, the rest of the items become statistically significant and go in the expected direction when using POPPA classification, which excludes La République en Marche and includes the French Communist Party. Furthermore, some of the other issues exhibit higher coefficients, as Pop6 (-0.53), Pop2 (-0.49), and Pop4 (-0.37).

The relatively good fit of the CSES attitudinal items with the POPPA supply-side classification seems to indicate that in the case of France the problem of congruence is not so much due to the choice of attitudinal items but to the assessment made by the CSES experts on the level of populism of the parties included. 
Figure 5. Average marginal effects on the probability to cast a vote for a populist party instead of other parties, the case of France
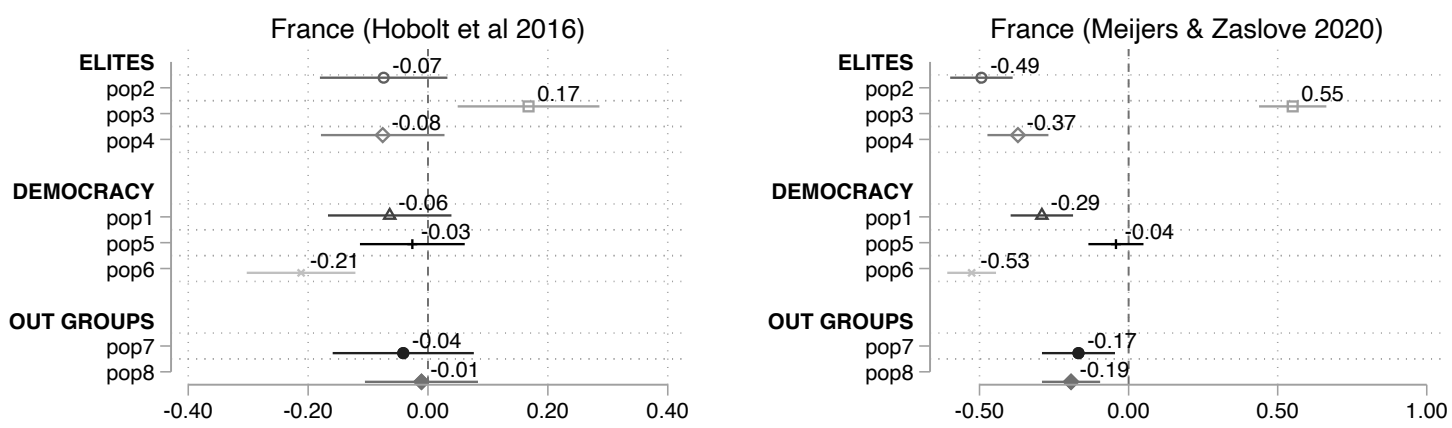

Source: Own elaboration based on CSES Module 5 and Meijers and Zaslove (2020b)

CSES acknowledges the multidimensionality of the phenomenon, and accordingly designs items to capture some of these components in citizens' attitudes (Hobolt et al., 2016: 5-10). However, this logic was not followed when assessing parties, and CSES experts were not requested or had the choice to reflect on different components or attributes. CSES Module 5 simply provides a definition but does not require a justification on why the overall score was achieve. More explicit rules in terms of the criteria or dimensions that should be taken into consideration or potential benchmarks which could be considered in the evaluation may help standardize the analysis across experts and countries. More recent studies, such as Meijers and Zaslove's (2020a: 13) POPPA, and Norris' (2020: 10) Global Party Survey, on the other hand, include expert surveys items which try to mirror those usually encountered in the demand-side scales, and conduct robustness tests and comparisons with other measures.

Although the CSES used a gradient system and did not include any explicit threshold to distinguish 'populist' from 'non populist' parties, some of the existing studies on the supply side include binary (e.g. PopuList) or three-ways (e.g. Hawkins, 2009) assessments. These approaches may lead to additional problems especially in borderline cases.

However, Figure 6 shows problems of congruence between the supply- and demandside measurements in Hungary even when adopting the POPPA classification. Half of the items (Pop3, Pop1, Pop6 and Pop7) are not correlated in a statistically significant way with support to populist parties. Interestingly, another two items, Pop2 and Pop4, being statistically significant, display unexpected directions (positive). Thus, the Hungarian example indicates that the mismatch cannot be attributed to party classification. Country- 
specific cultural and political characteristics deserve further attention as voters may not understand the questions in the same way in every country and in some of them, parties classified as populist may not differ so significantly from their competitors (Pirro, 2015).

Figure 6. Average marginal effects on the probability to cast a vote for a populist party instead of other parties, the case of Hungary
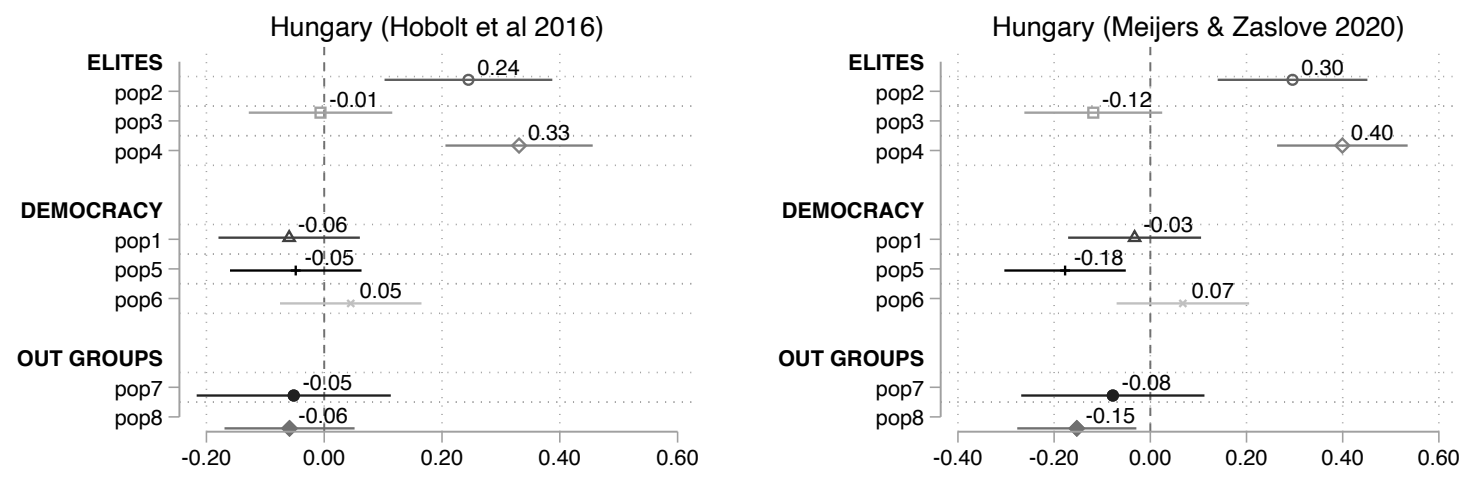

Source: Own elaboration based on CSES Module 5 and Meijers and Zaslove (2020b)

\section{Conceptualisation biases}

Different conceptualisations or emphasis on specific populist attributes can also explain why some approaches work in some regional contexts but not in others (De la Torre and Mazzoleni 2019: 81-85, 90-91). Similarly, the conflation of populism with exclusionary right-wing nationalism in the literature (De Cleen and Stavrakakis 2017) contributes to create some problems when it comes to measure attitudes and parties. The existence of varieties within populism (Berlin 1968: 138-155; Müller 2016: 11-19) makes more difficult the process of selecting items and components which should be wide enough to encompass different types of movements but at the same sufficiently specific to discriminate populist from non-populist profiles on both sides of the left-right continuum.

\section{Figure 7. Average marginal effects on the probability to cast a vote for a populist} (left $v s$ right) party, Greece
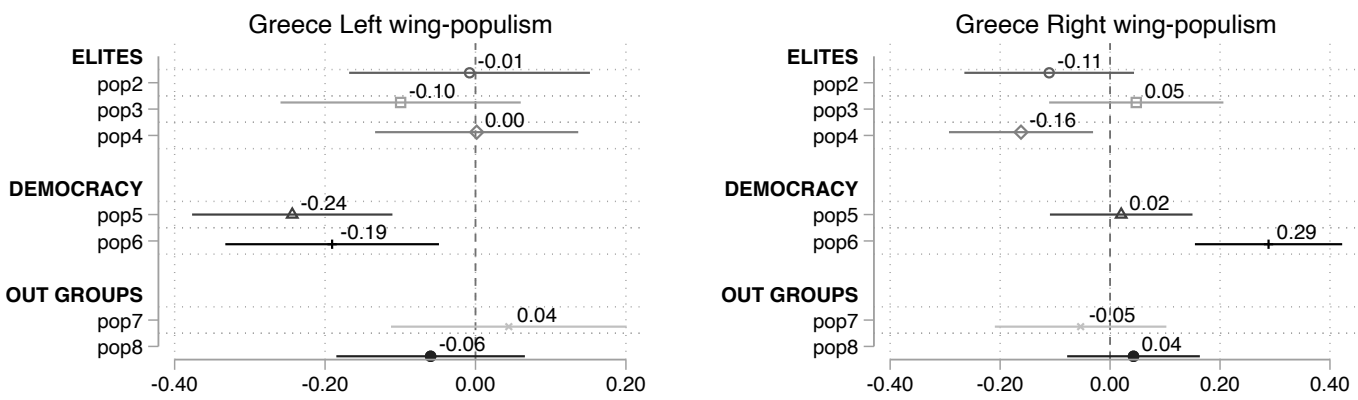

Source: Own elaboration based on CSES Module 5 
Figure 7 illustrates this particular issue in the context of the CSES Module 5 measures by disentangling left-wing and right-wing Greek populist parties. ${ }^{\text {xiii }}$ Several interesting results emerge. ${ }^{x i v}$ Firstly, Pop4 (elite dimension) works as a better predictor for the rightwing populist parties than for the left-wing ones. Secondly, Pop7 (out-groups dimension), which is the sole statistically significant item when considering all populist parties together, cease to become a statistically significant predictor in both, the case of right and left-wing populism. This contradicts the generally held assumption that left-wing populism is predominantly in favour of allowing minorities to maintain their distinct customs and traditions, but is not completely surprising as previous research suggests that left-wing populist parties may display as well a certain nativist component (Santana and Rama 2018). Finally, Pop6, that did not have any statistically significant impact when considering all populist parties, displays now opposite, and significant, results in left- and right-wing populism. It suggests that, at least in Greece, voters of left-wing populist parties are statistically in favour of more direct democracy, while supporters of the rightwing populist parties prefer to keep the decisions politicians' hands. ${ }^{\mathrm{xxv}}$ In sum, the case of Greece illustrates how some items may work only when considering a specific type of populism.

\section{Conclusions}

Numerous studies have focused on how to measure populist attitudes and beliefs via survey analysis. Similarly, social scientists have devised several tools to classify political parties as populist and non-populist. Although both the analyses of demand- and supplyside of populism have grown in popularity and sophistication, they have followed parallel but separate ways. Moreover, there are still open conceptual debates on the definitional attributes of populism that should be used to adequately measures populist attitudes and classify political parties. The analysis of congruence between the supply-side and demand-side of populism is important because it can help reveal potential problems in the items used to measure populist attitudes, issues at the level of the internal processes and criteria applied to classify political parties as populist. Moreover, it can contribute to better understand different dynamics and ideational links between populist parties and their potential voters. Unfortunately, these studies remain scarce and most existing 
instruments were not created paying much consideration to their compatibility with those applied in the other side of this supply-demand divide.

Our analysis of congruence based on the Comparative Studies of Electoral Systems (CSES) Module 5 dataset and complemented with the recent Populism and Political Parties Expert Survey (POPPA) shows that the predictive capacity of some of the items, typically considered as indicators of populism, is limited, and in some countries there is an almost complete mismatch between support for parties classified as populist and the level of populist attitudes among voters. This article is not meant to be a critique to CSES approach but uses this influential and rich study to illustrate certain shortcomings and challenges that should be considered when attempting to measure populism. We acknowledge that this and several other important contributions mentioned above have played a key role in the development of the first few tools to measure rigorously this complex latent construct. However, as our study unveils, there are a series of problems that may remain undetected if we continue to develop separately instruments and criteria to measure the demand and supply-sides of populism. Our analysis of congruence of the CSES Module 5 data indicates a limited correlation between populist attitudes and support for populist parties in 10 out of the 17 countries analysed. Congruence is only partial in France and Lithuania (only some attitudinal populist dimensions are correlated with 'populist' vote), and null in other countries, such as Brazil, Korea and Greece. The lack of congruence is particularly significant among the group of non-European countries analysed as we find 'populist voters' to be more prone to endorse parties classified as 'populist' in only 2 -i.e. USA and Australia - out of the 7 cases studied. This may be an indication that the items and criteria used to measure populism work better in a Western context.

In our analysis we show that some of the items employed in the CSES Module 5 to measure the demand-side could be either replaced or refined. In addition to items validation via expert consultation, statistical methods such as confirmatory factor analysis (CFA) and item response theories (IRT) are increasingly used in pilot empirical studies to help test and improve the choice of dimensions, items and wordings. Our graded response model (GRM) suggests that the two related to the elite dimension were the only ones that significantly help discriminate between 'populist' and 'non-populist' voters in the CSES Module 5.

Populism is considered a complex phenomenon and an increasing number of authors adopt a multidimensional angle to operationalize it. CSES applies a multidimensional 
logic when studying the demand-side, but it does not use a multidimensional assessment of populism when it comes to parties. Moreover, the disparities with the POPPA scores, and the fact that in some cases we find more congruence between the CSES Module 5 measurement of populist attitudes and the POPPA assessment of parties' populism, than when using the former in both instances, seem to suggest some issues with the CSES supply-side assessment, at least in some countries. A more explicit process of selection of experts, definition of evaluation criteria and validation of results, as those followed in POPPA should be considered in future supply-side studies.

Additionally, we prove that populism instruments can be better suited to measure a specific variety of populism than others. Some of the items which may not be good predictors of populist vote in general, become statistically correlated with support for either left-wing or right-wing populist parties. This serves as a reminder of the challenge which entails creating a comparative fit-for-all tool to reliably capture different varieties of populism across diverse political contexts.

In sum, this paper invites populism scholars to take into consideration both sides of populism when creating new instruments, and to adopt consistent and explicit criteria in their empirical work. Some of the problems of congruence detected in this paper could be properly addressed if the data collected had a similar granularity/dimensionality. A consistent approach to the study of the demand- and supply-sides of populism would facilitate the detection of design problems and help test some of the longstanding theoretical assumptions in this field concerning varieties of populism, the relative centrality of attributes/dimensions, and the connection between populist parties and their voters. 


\section{References}

Akkerman A, Mudde C and Zaslove A (2014) How Populist are the People?

Measuring Populist Attitudes in Voters, Comparative Political Studies, 47(9), 1324 $-1353$

Akkerman, A, Zaslove, A, and Spruyt, B (2017). 'We the people'or 'we the peoples'? A comparison of support for the populist radical right and populist radical left in the Netherlands. Swiss Political Science Review, 23(4), 377-403.

Albertazzi D and McDonnell D (2008) Introduction: The sceptre and the spectre. In Twenty-first century populism (eds.). Palgrave Macmillan, London.

Bell J (1992) Populism and Elitism: Politics in the Age of Equality. Washington D.C.: Regnery Gateway

Berlin I (1968) To define Populism. Government and Opposition 3(2), 137-79

Bernhard L and Kriesi H (2019) Populism in election times: A comparative analysis of 11 countries in Western Europe. West European Politics, 42(6), 1188-1208.

\section{Castanho Silva B, Andreadis I, Anduiza E, Blanusa N, Corti YM, Delfino G, Rico} G, Ruth S, Spruyt B, Steenbergen MR and Littvay L (2018) Public opinion surveys: A new scale. In K. A. Hawkins, R. Carlin, L. Littvay, and C. Rovira Kaltwasser (Eds.), The Ideational Approach to Populism: Concept, Theory, and Analysis. New York: Routledge.

Castanho Silva B, Jungkunz S, Helbling M and Littvay L (2020) An empirical comparison of seven populist attitudes scales. Political Research Quarterly, 73(2), 409-424.

Castles F G and Mair P (1984) Left-right political scales: Some 'expert'judgments. European Journal of Political Research, 12(1), 73-88.

Coppedge M (1997) A Classification of Latin American Political Parties (Notre Dame: Working Paper Series, Kellogg Institute of International Studies, University of Notre Dame. Available at https://kellogg.nd.edu/documents/1539 
CSES (2020) CSES Module 5: 2016-2021 Comparative Study of Electoral Systems, available at https://cses.org/data-download/cses-module-5-2016-2021/

De Cleen B and Stavrakakis Y (2017) Distinctions and Articulations: A Discourse Theoretical Framework for the Study of Populism and Nationalism. Javnost: The Public, 24(4), 301-319.

De la Torre C and Mazzoleni $O$ (2019) Do We Need a Minimum Definition of Populism? An Appraisal of Mudde's Conceptualization. Populism 2, 79-95

Depaoli S, Tiemensma J and Felt JM (2018) Assessment of health surveys: fitting a multidimensional graded response model. Psychology, Health and Medicine, 23:sup1, 1299-1317.

Elchardus M and Spruyt B (2016) Populism, Persistent Republicanism and Declinism: An Empirical Analysis of Populism as a Thin Ideology. Government and Opposition, 51(1), 111-33.

Embretson S and Reise S (2000) Item response theory for psychologist. Mahwah: Lawrence Erlbaum.

Gidron N and Bonikowski B (2013). Varieties of populism: Literature review and research agenda (Weatherhead Center for International Affairs, 13-0004). Cambridge, MA: Harvard University. Available at https://scholar.harvard.edu/files/gidron bonikowski populismlitreview 2013.pdf

Givens TE (2005) Voting Radical Right in Western Europe. New York: Cambridge University Press.

Gunther R and Diamond L (2003) Species of political parties: A new typology. Party politics, 9(2), 167-199.

\section{Hawkins KA, Aguilar R, Castanho Silva B, Jenne EK, Kocijan B, and Rovira} Kaltwasser C (2019) Measuring Populist Discourse: The Global Populism Database. Working Paper presented at the 2019 EPSA Annual Conference in Belfast, UK, June 20-22. Available at 
https://populism.byu.edu/App Data/Publications/Global\%20Populism\%20Databas e\%20Paper.pdf

Hawkins KA, Rovira Kaltwasser C and Andreadis I (2020) The activation of populist attitudes. Government and Opposition, 55(2), 283-307.

Hawkins KA, Riding S and Mudde C (2012) Measuring populist attitudes. Political Concepts Committee on Concepts and Methods Working Paper Series, 55, 1-35.

Hawkins KA (2009) Is Chavez populist? Measuring populist discourse in comparative perspective. Comparative Political Studies, 42(8), 1040-1067.

Hobolt S, Anduiza E, Carkoglu A, Lutz G and Sauger N (2016) Democracy

Divided? People, Politicians and the Politics of Populism. Available at https://cses.org/wp-

content/uploads/2019/03/CSES5_ContentSubcommittee_FinalReport.pdf

Hopkin J and Blyth M (2019) The global economics of European populism: growth regimes and party system change in Europe. Government and Opposition, 54(2), 193-225.

Ionescu G and Gellner E (1969) Introduction. In Ionescu, G. and Gellner E. (eds) Populism - Its Meanings and National Characteristics. London: Weidenfeld and Nicolson.

Jagers J and Walgrave S (2007). Populism as political communication style: An empirical study of political parties' discourse in Belgium. European Journal of Political Research 46(3), 319-345

James G, Witten D, Hastie T and Tibshirani R (2017) An Introduction to Statistical Learning: with Applications in R. New York: Springer

Laclau E (2005) On populist reason. Politics/philosophy. London: Verso.

Mair P and Mudde C (1998) The Party Family and its Study. Annual Review of Political Science, 1(1), 211-229. 
March L and Mudde C (2005) What's Left of the Radical Left? The European Radical Left After 1989: Decline and Mutation, Comparative European Politics, 3: 23-49

Marcos-Marne H (2020) A Tale of Populism? The Determinants of Voting for LeftWing Populist Parties in Spain. Political Studies, 0032321720950215.

Meijers MJ and Zaslove A (2020a) Measuring Populism in Political Parties: Appraisal of a New Approach. Comparative Political Studies. doi.org/10.1177/0010414020938081

Meijers MJ and Zaslove A (2020b), Populism and Political Parties Expert Survey 2018 (POPPA), https://doi.org/10.7910/DVN/8NEL7B, Harvard Dataverse: https://dataverse.harvard.edu/dataset.xhtml?persistentId=doi\%3A10.7910\%2FDVN \%2F8NEL7B.

Meléndez C and Rovira Kaltwasser C (2019) Political Identities: The Missing Link in the Study of Populism. Party Politics 25(4): 520-533.

Moffitt B (2016) The global rise of populism: Performance, political style, and representation. Stanford: Stanford University Press.

Mohrenberg S, Huber RA and Freyburg T (2019) Love at first sight? Populist attitudes and support for direct democracy. Party Politics https://doi.org/10.1177/1354068819868908

Mudde C (2004) The populist zeitgeist. Government and Opposition, 39(3), 541- 563.

Mudde C (2007) Populist radical right parties in Europe. Cambridge University Press

Müller JW (2016) What is Populism? Philadelphia: University of Pennsylvania Press

Norris P (2020) Measuring Populism Worldwide. Faculty Research Working Paper Series. February 2020, available at https://papers.ssrn.com/sol3/Delivery.cfm/SSRN ID3541314 code385205.pdf?abs tractid $=3541314 \&$ mirid $=1$ 
Norris P and Inglehart R (2019) Cultural backlash: Trump, Brexit, and authoritarian populism. Cambridge University Press.

Ostiguy P, Panizza F and Moffitt B (2021 eds.) Populism in Global Perspective: A Performative and Discursive Approach. New York: Routledge.

Olivas Osuna JJ (2020) From chasing populists to deconstructing populism: a new multidimensional approach to understanding and comparing populism, European Journal of Political Research, https://doi.org/10.1111/1475-6765.12428

Oliver JE and Rahn WM (2016) Rise of the Trumpenvolk. The ANNALS of the American Academy of Political and Social Science, 667(1), 189-206.

Panizza F (2017) Populism and Identification. In Rovira-Kaltwasser, C., Taggart, P. Ochoa-Espejo, P. and Ostiguy, P. (eds), The Oxford Handbook of Populism. Oxford: Oxford University Press.

Pauwels T (2011) Measuring Populism: A Quantitative Text Analysis of Party Literature in Belgium, Journal of Elections, Public Opinion and Parties, 21(1), 97119.

Pirro A (2015) The Populist Radical Right in Central and Eastern Europe. New York, NY: Routledge.

Polk J, Rovny J, Bakker R, Edwards EE, Hooghe L, Jolly S, Koedam J, Kostelka F, Marks G, Schumacher G, Steenbergen M, Vachudova $M$ and Zilovic M (2017) Explaining the salience of anti-elitism and reducing political corruption for political parties in Europe with the 2014 Chapel Hill Expert Survey Data. Research and Politics, 4(1), 205316801668691.

Rama J and Casal-Bértoa F (2020) Are Anti-Political-Establishment Parties a Peril for European Democracy? A Longitudinal Study from 1950 till 2017, Representation, 56(3): 387-410.

Rodrik D (2018) Populism and the Economics of Globalization. Journal of International Business Policy, 1, 12-33. 
Rooduijn M, and Pauwels T (2011) Measuring populism: Comparing two methods of content analysis. West European Politics, 34(6), 1272-1283.

Rooduijn M, Van Kessel S, Froio C, de Lange SL, Halikiopoulou D, Lewis PG, Mudde C and Taggart P (2019) The PopuList: An overview of populist, far right, far left and Eurosceptic parties in Europe. http://www.popu-list.org

Rooduijn M, de Lange SL and Van der Brug W (2014) A populist Zeitgeist? Programmatic contagion by populist parties in Western Europe. Party politics 20(4), 563-575.

Rovira-Kaltwasser C, Taggart P, Ochoa-Espejo P and Ostiguy P (2017) Populism: The State of the Are In Rovira-Kaltwasser, C., Taggart, P. Ochoa-Espejo, P. and Ostiguy, P. (eds), The Oxford Handbook of Populism. Oxford: Oxford University Press.

Rovira-Kaltwasser C and Van Hauwaert SM (2020) The populist citizen: Empirical evidence from Europe and Latin America. European Political Science Review, 12(1), 1-18.

Santana A and Rama J (2018) Electoral Support for Left Wing Populist Parties in Europe: Addressing the Globalization Cleavage, European Politics and Society, 19(5), 558-576.

Schulz A, Müller Ph, Schemer C, Wirz DS, Wettstein M and Wirth W (2018) Measuring Populist Attitudes on Three Dimensions. International Journal of Public Opinion Research 30(2), 316-26.

Spruyt B, Keppens G and van Droogenbroeck F (2016) Who Supports Populism and What Attracts People to It? Political Research Quarterly 69(2), 335-46.

Taggart P (2000) Populism. Buckingham: Open University Press.

Ţăranu A (2012) Populism as the 'democratic malaise'. European Journal of Science and Technology, 8(suppl. 1), 131-141. 
Van Hauwaert SM, Schimpf C and Azevedo F (2020) The Measurement of Populist Attitudes: Testing Cross-National Scales Using Item Response Theory, Politics, $40(1), 3-21$.

Van Hauwaert SM and Van Kessel S (2018) Beyond protest and discontent: A crossnational analysis of the effect of populist attitudes and issue positions on populist party support. European Journal of Political Research, 57(1): 68-92.

Van Kessel S (2015) Populist parties in Europe. Agents of discontent? Basingstoke: Palgrave Macmillan.

Weyland K (2001) Clarifying a contested concept: Populism in the study of Latin American politics. Comparative Politics, 34(1), 1-22.

Williams R (2012) Using the Margins Command to Estimate and Interpret Adjusted Predictions and Marginal Effects. Stata Journal, 12 (2), 308-31.

Wiesehomeier N (2019) Expert surveys. In Hawkins, K. A., Carlin, R.E., Littvay, L. and Rovira-Kaltwasser (eds). The Ideational Approach to Populism: Concept, Theory, and Analysis. London: Routledge.

Wuttke A, Schimpf C and Schoen H (2020) When the whole is greater than the sum of its parts: On the conceptualization and measurement of populist attitudes and other multi-dimensional constructs. American Political Science Review, 114(2), $356-374$.

Zanotti L and Rama J (2020) Support for liberal democracy and populism: A pilot survey for young educated citizens. Political Studies Review. DOI: https://doi.org/10.1177/1478929920945856

Zaslove A (2008) Here to Stay? Populism as a New Party Type, European Review 16(03),319-336. 


\section{Appendix: Robustness Checks}

Table A1. Logistic and linear regression of the pooled dataset with country fixed effects

\begin{tabular}{lcc}
\hline & $\begin{array}{c}\text { Model 1 } \\
\text { Logistic }\end{array}$ & $\begin{array}{c}\text { Model 2 } \\
\text { OLS }\end{array}$ \\
\hline Elites & $-0.25^{*}$ & $-0.06^{*}$ \\
pop2 & $(0.12)$ & $(0.03)$ \\
pop3 & $0.31^{*}$ & $0.07^{* *}$ \\
& $(0.10)$ & $(0.02)$ \\
pop4 & $-0.24^{*}$ & $-0.06^{*}$ \\
& $(0.11)$ & $(0.02)$ \\
Democracy & & \\
pop1 & -0.14 & -0.03 \\
& $(0.08)$ & $(0.02)$ \\
pop5 & -0.12 & -0.03 \\
& $(0.07)$ & $(0.02)$ \\
pop6 & $-0.22^{* *}$ & $-0.05^{* *}$ \\
& $(0.07)$ & $(0.01)$ \\
Out-groups & & \\
pop7 & -0.25 & -0.06 \\
& $(0.70)$ & $(0.17)$ \\
pop8 & $-1.16^{*}$ & $-0.28^{*}$ \\
& $(0.56)$ & $(0.12)$ \\
\hline Controls & \multicolumn{3}{c}{ YES } & YES \\
\hline \multirow{3}{*}{ Robust standard errors in parentheses } \\
$* * *$ p $<0.001, * *$ p $<0.01, * \mathrm{p}<0.05$ \\
\end{tabular}

Note: Number of observations for Pop1: 16,229; Pop2: 19,313; Pop3: 19,257; Pop4: 19,145; Pop5: 19,130; Pop6: 19,235; Pop7: 19,252; Pop8:18,985

Source: Own elaboration based on CSES 
Figure A1. Ordinary least square, vote for populist parties in non-European countries
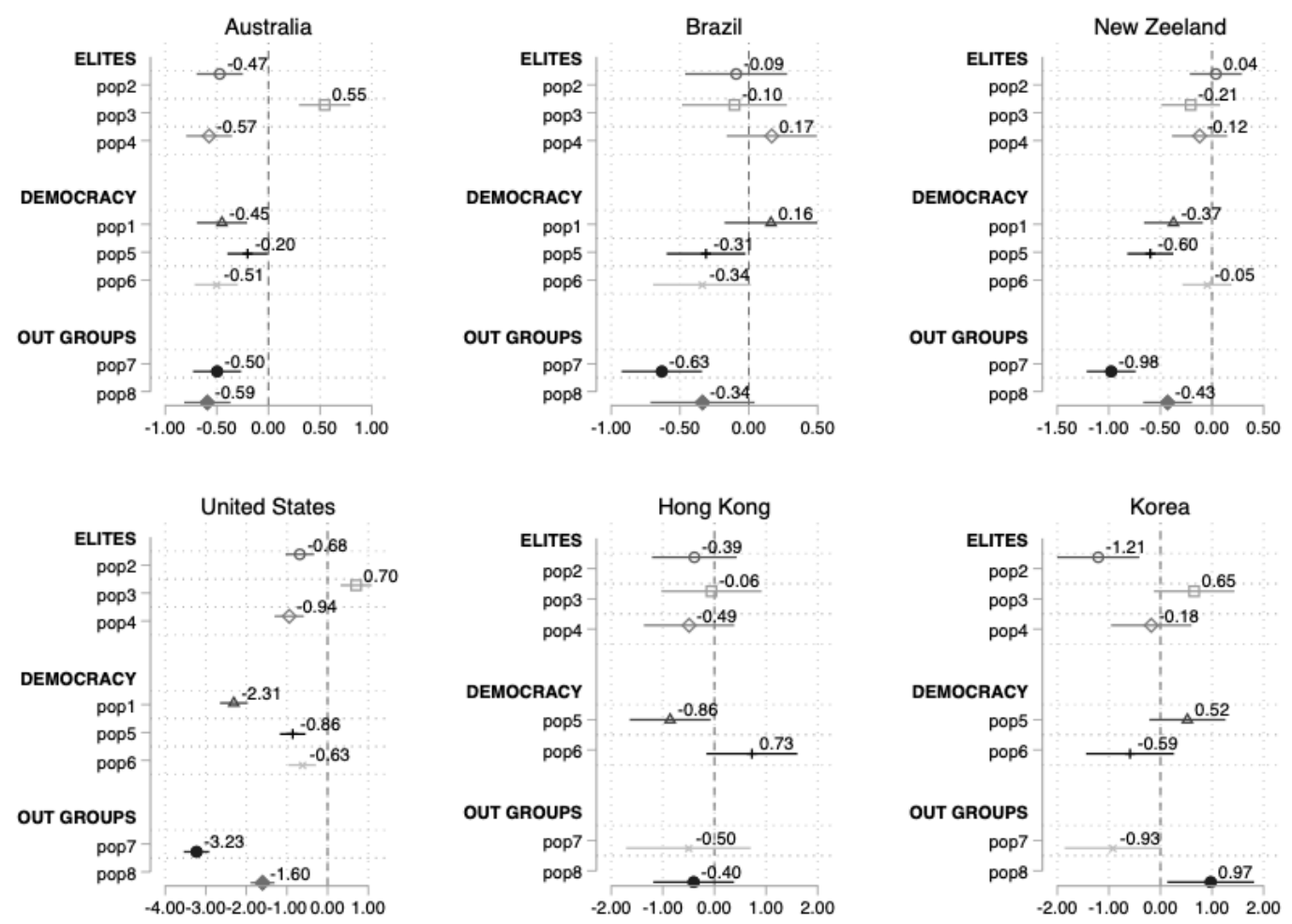

Figure A2. Ordinary least square, vote for populist parties in European countries
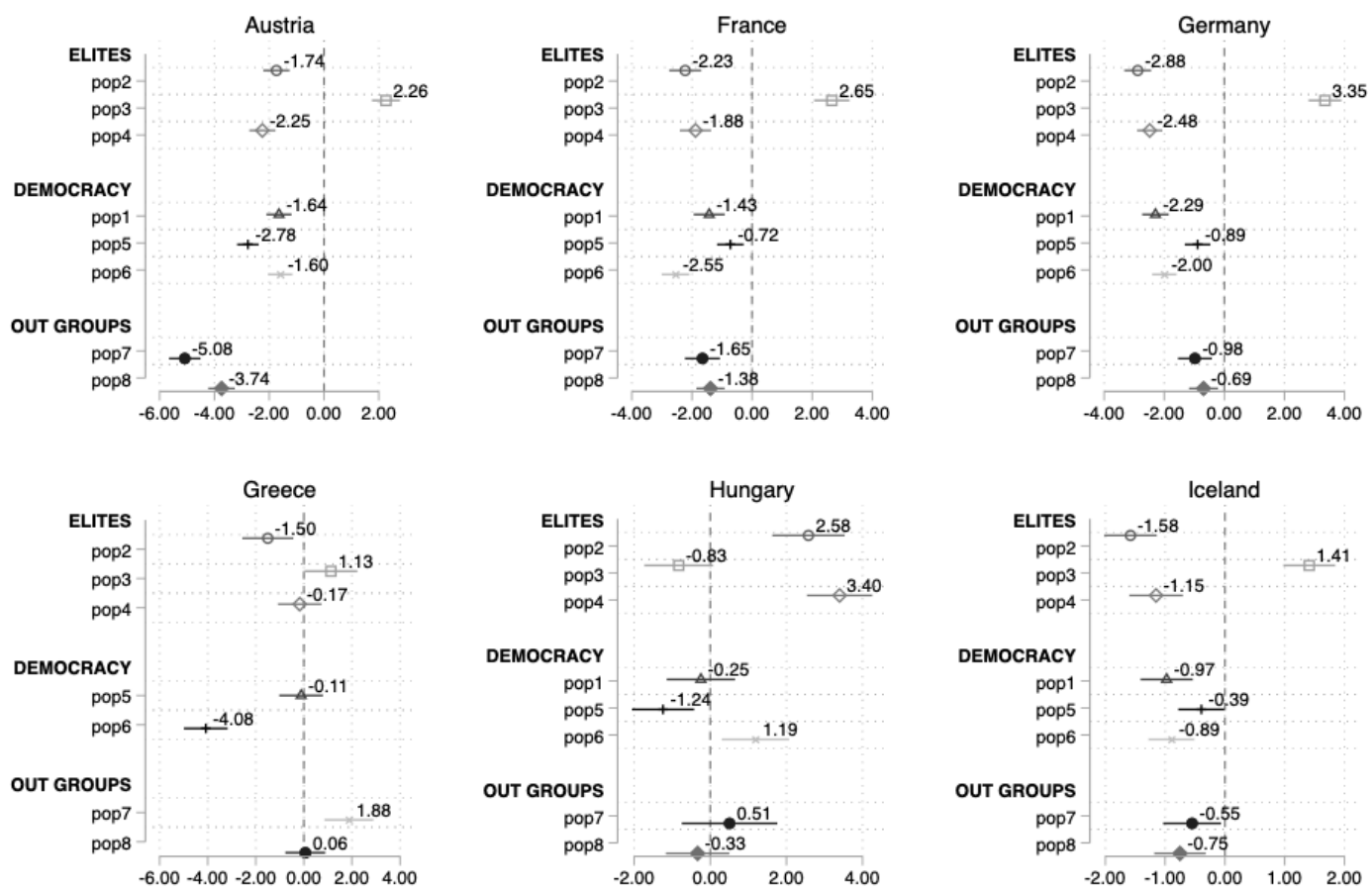

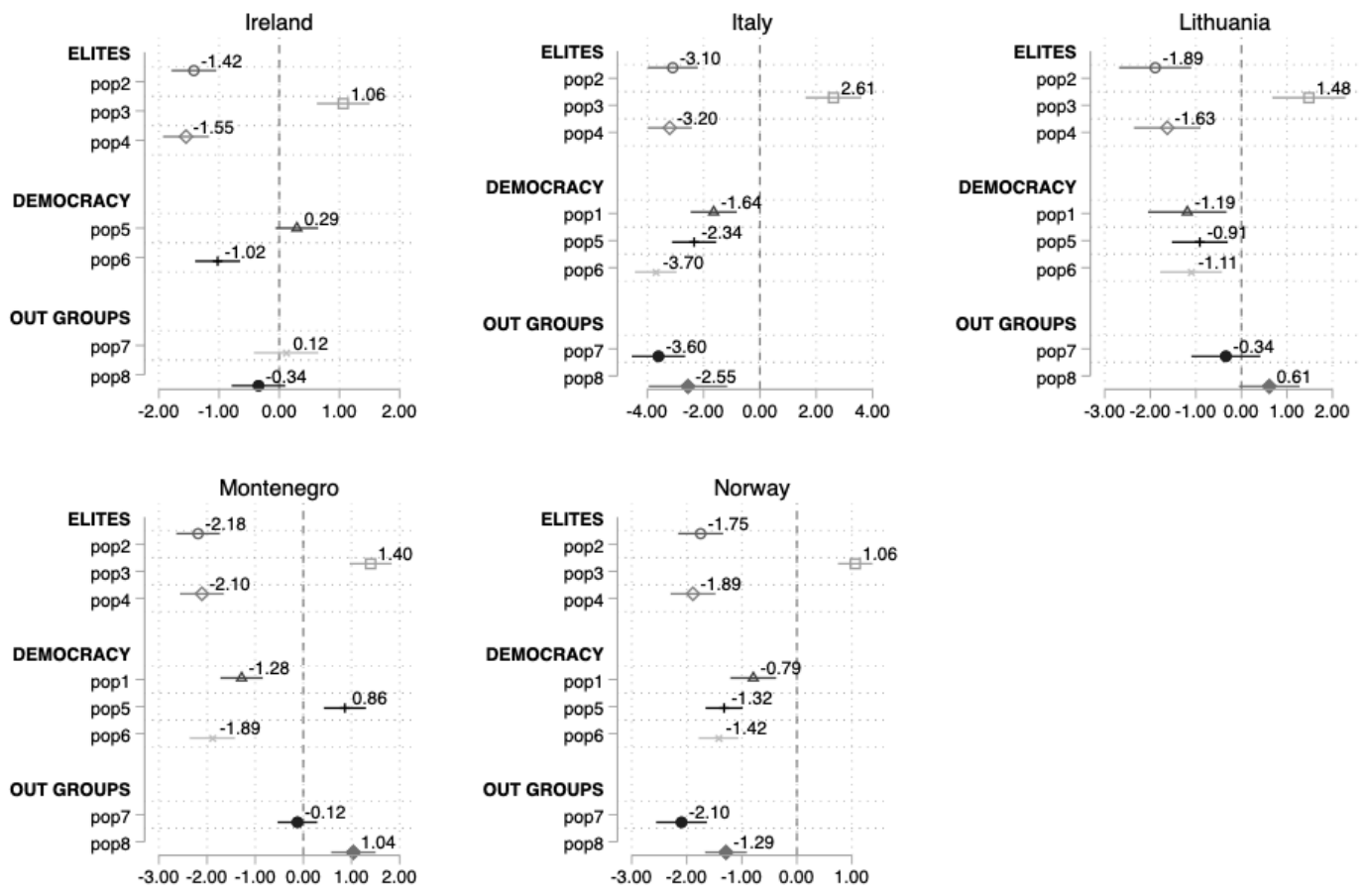

\section{Notes}

\footnotetext{
${ }^{i}$ Some of the most vivid examples are the Dutch Socialist Party (SP) or Forza Italia (FI). The first one, is considered populist by March and Mudde (2005), but not by Van Kessel's (2015: 60), whereas FI is considered populist by Zaslove (2008) but not by Van Kessel (2015: 54).

ii This scale originally included 8 items to reflect populist attitudes, 3 items about elitist attitudes and 3 items on pluralist ones. From the 8 populist items, they exclude in the analysis two dimensions: pop6: and pop8..

iii The construct validity and ability to capture multidimensionality has been questioned (Meijers and

Zaslove 2020a: 4-5).

iv The PopuList classifies political parties under the labels of populism, far-right, far-left and/or Eurosceptic ( $1=$ if the party belongs to this label; $0=$ if the party doesn't belong to).

v The question wording: 'Parties can also be classified by their current use of POPULIST OR

PLURALIST rhetoric. POPULIST language typically challenges the legitimacy of established political institutions and emphasizes that the will of the people should prevail. By contrast, PLURALIST rhetoric rejects these ideas, believing that elected leaders should govern, constrained by minority rights, bargaining and compromise, as well as checks and balances on executive power.' (Norris 2020: 10) Where would you place each party on the following scale? From 0 ("Strongly favors pluralist rhetoric") to10 ("Strongly favors populist rhetoric")

${ }^{v i}$ CSES Module 5 also contains items referring to other variables such as political interest, politics in the media, internal efficacy, attitudes toward redistribution, government performance, state of the economy and vote choice (Hobolt et al. 2016: 12).

vii CSES Module 5 includes another item related to a general perception of corruption among politicians (Q7) but we consider that its wording makes it a weaker item to predict individuals' populist attitudes.

viii It is worth noting that CSES Module 5 included other items for this dimension Q5b-d and Q6b-d, but for simplicity's sake we have only used the first of each of these broader questions. We previously checked the correlation between the different questions. Regarding the battery of questions of national identity (Q6a, Q6b, Q6c and Q6d) the correlation coefficient is major than 0.4 for all pairs of correlations with the exception of Q6d, related to country's customs and traditions. Question Q6a was selected for our analysis given that it presented the best fit among these 4 questions. The battery of questions of outgroups, displays different approximations to the attitudes towards immigrants, focusing on the effects of immigrants on the country's economy (Q5c), the country's culture (Q4d), and the country's crime levels
} 
(Q5e). The item selected (Q5a) focuses on the right of minorities to keep their customs and traditions. Q6b, although also referring to minorities ('The will of the majority should always prevail even over the rights of minorities'), it seems to introduce a majoritarian or people centric component which may overshadow the minority component.

ix The exact wording is: 'Please indicate the degree to which each of the parties can be characterized as a populist party. Populism can be defined as a thin-centered ideology that pits a virtuous and homogeneous people against a set of elites and dangerous "others" who are depicted as depriving the sovereign people of their rights, values, prosperity, identity, and voice. The emphasis on anti-elite/ anti-establishment rhetoric and the contrast between the "pure people" and the "corrupt elite" are thus indications of the degree to which a party is populist. Populist parties may be found across the left-right ideological spectrum.

On a scale of 0 to 10 , where 0 is "not at all populist" and 10 is "very populist", where would you place each of the parties?'

${ }^{x}$ CSES published online a Macro Report for each of the countries available at https://cses.org/datadownload/cses-module-5-2016-2021/ . These reports contain the assessment of experts on populism and other areas of the study.

${ }^{x i}$ We have excluded Chile due to data inconsistencies. All parties score 1, except for Partido Progresista which has a populism score of 2. Macro Report available at https://cses.org/datacenter/module5/macro/CHL 2017 Macro.pdf,

xii CSES Module 5 assessment did not allow for decimals.

xiii No assessment of populism was made by CSES country experts on Taiwan and Turkey.

${ }^{\mathrm{xiv}}$ For the sake of robustness, we replicate this analysis using ordinary least squares (OLS) regressions and found results consistent with those in our logistic model (Figure A1 and A2 in the Appendix). All countries display equivalent results in both logistics and linear regressions. France is the sole exception and this anomaly is presumably due to some missing values. In this specific case, CSES country experts did not give a score to non-populist parties and therefore they are absent from our OLS model. We also run logistic and linear regressions for the pooled dataset specifying country fixed effects (see Table A1). The results are consistent with those in the abovementioned country by country analyses.

${ }^{\mathrm{xv}}$ The choice to dichotomize the level of populism in our analysis $(1=$ 'populist party' - $0=$ 'nonpopulist party') used is not an unusual approach (e.g. Mudde 2007; Rooduijn et al. 2020). It facilitates the visualisation of the analyses conducted. Moreover, the Average Marginal Effects (AMEs) is a statistical technique which helps interpret the impact of each of the eight items on the likelihood of voting for a populist party rather than for other political options. It is based on a binomial logistic regression. Finally, a dichotomisation seemed also the best option given that some CSES country expert reports did not include a score for some of the supposedly non-populist parties, this means that in the OLS regression analysis (see Figure A1 and A2) we lost some cases.

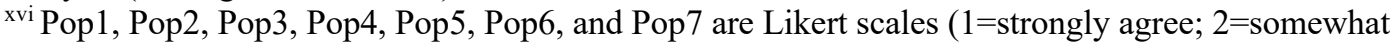
agree; $3=$ neither agree nor disagree; $4=$ somewhat disagree; $5=$ strongly disagree) whereas pop 8 is a categorical variable with four options ( $1=$ very important; $2=$ Fairly important; $3=$ not very important; $4=$ not important at all). We create a dichotomous populist support variable $(0=$ casting a vote for a nonpopulist party; $1=$ casting a vote for a populist party).

${ }^{x v i i}$ We divided by five pop items in order to obtain variables that ranges from 0 to 1 for a correct interpretation of the AMEs coefficients (this rescaling is neutral in terms of significance levels and does not affect the AMEs).

xviii We invert Pop3 to make it follow the same (negative) direction than the rest of the items. This is similar to what Akkerman et al. (2014: 1336) and Elchardus and Spruyt (2016) do by creating an additive index with all the items, but different from Castanho Silva et al.'s (2018) and Schulz et al.'s (2018) approaches.

xix Rovira-Kaltwasser and Van Hauwaert (2020: 9) measure populist attitudes using items from previous scales and show surprising results. For instance, Mexico, which is ruled by a widely considered populist President, display very low average populist attitudes scores; much lower than countries such as France or Spain.

${ }^{x x}$ Both techniques are very useful at survey development stage. While CFA examines covariances between different items, and constructs a linear response between the factor/dimension and item response, IRT assesses the overall response patterns across all items so that no information of the data is lost, and constructs a nonlinear relationship between latent traits and item responses (Depaoli et al. 2018: 1301; Embretson and Reise 2000: 37-38)

xxi Given the continuous nature of the eight items to measure populist attitudes, we estimate Graded Response Models (GRM) instead of IRTs. GRM is based on a cumulative log-odds principle, in which the probabilities of choosing a given response category within each item is modelled as differences between cumulative probabilities (Van Hauwaert et al. 2020). 
xxii Castanho Silva et al.'s (2019) CFA of the CSES scale suggests dropping the worst indicator.

${ }^{x x i i i}$ L.S.-X.A. (Golden Dawn), AN.EL. and E.K. on the right and Syriza and K.K.E. on the left.

xxiv As well as control by sociodemographic factors (e.g. age, educational level and gender) we also include voter's left-right self-placement, in order to deal with false correlations.

${ }^{x x v}$ Pop5 is not statistically significant for the case of right-with populist parties, having a negative and significant effect to understand the left-wing populist vote 